University of Nebraska - Lincoln

DigitalCommons@University of Nebraska - Lincoln

1982

\title{
The Distribution of Natural Fractures and Joints at Depth in Crystalline Rock
}

Donald A. Seeburger

Stanford University

Mark D. Zoback

U.S. Geological Survey, zoback@stanford.edu

Follow this and additional works at: https://digitalcommons.unl.edu/usgsstaffpub

Part of the Earth Sciences Commons

Seeburger, Donald A. and Zoback, Mark D., "The Distribution of Natural Fractures and Joints at Depth in Crystalline Rock" (1982). USGS Staff -- Published Research. 454.

https://digitalcommons.unl.edu/usgsstaffpub/454

This Article is brought to you for free and open access by the US Geological Survey at DigitalCommons@University of Nebraska - Lincoln. It has been accepted for inclusion in USGS Staff -- Published Research by an authorized administrator of DigitalCommons@University of Nebraska - Lincoln. 


\title{
The Distribution of Natural Fractures and Joints at Depth in Crystalline Rock
}

\author{
DONALD A. SEebURGeR ${ }^{1}$ \\ Geophysics Department, Stanford University, Stanford, California 94305
}

MARK D. ZoBacK

U.S. Geological Survey, Menlo Park, California 94025

\begin{abstract}
This paper presents the results of studies of the natural fracture distribution encountered in 10 test wells drilled in three areas of the United States. Seven of the wells were drilled to depths of $200-250 \mathrm{~m}$, while three were drilled to depths of about $1 \mathrm{~km}$. Using an ultrasonic borehole televiewer, fracture depths, strikes, and dips were determined. Steeply dipping fractures were found throughout each of the wells, and in general, few horizontal fractures were observed. Statistically significant fracture pole concentrations were found for each well which were basically invariant with depth, although some variation of fracture orientation with depth was found in two wells. The significant fracture orientations were not found to be the same in wells only several kilometers apart in a given region. In none of the wells did the number of observable fractures decrease markedly with increasing depth. No simple relationship of fracture orientation or fracture density with major structural features such as the San Andreas fault were observed, and no simple relation between the significant fracture orientations and either past or present regional stress fields could be determined.
\end{abstract}

\section{INTRODUCTION}

The upper crust of the earth is composed of fractured rock. Fractures are found on all scales from microfractures with dimensions of microns to lineaments with dimensions of kilometers. These fractures exert a profound effect upon the physical properties of rock. Laboratory and theoretical fracture studies have been extensive. Fractures have been found to affect the strength of rock [e.g., Brace, 1960], the velocity of elastic waves [e.g., Nur, 1971; Hadley, 1976], and the effective elastic moduli [e.g., Walsh, 1965; Budiansky and O'Connell, 1976]. The permeability and distribution of pore fluids in crystalline rocks are primarily determined by the density and distribution of fractures [e.g., Snow, 1968; Brace, 1980]. A knowledge of the in situ fracture distribution is thus of great importance for characterization of the upper crust. But systematic subsurface observations of fractures have been few. Most such observations have been made in tunnels and mines where the stress field and fracture pattern may have been considerably altered during operations. For example, McGarr [1971] and McGarr et al. [1979] studied the relation of fracture occurrence and rock bursts in deep mines. Fracture orientations were observed to be affected by the presence of the tabular excavations, and burst fractures were observed to occur where natural fractures were unusually sparse. Overbey and Rough [1971] compared fracture orientations measured at surface outcrops and from aerial photographs with those found in oriented cores and impression packer surveys of hydraulically fractured intervals in eastern Ohio. They found a fair degree of correlation between natural and induced fractures at depth and major fracture trends measured at the surface. The data discussed by Overbey and Rough [1971] are significant in that both the

\footnotetext{
'Now at Chevron Overseas Petroleum Inc., San Francisco, California 94105 .
}

This paper is not subject to U.S. copyright. Published in 1982 by the American Geophysical Union.

Paper number 2B0403. existence and the orientation of the fractures were determined; most borehole studies have been concerned with only the presence of fractures.

In this paper we present the results of in situ fracture studies performed in test wells drilled in three different regions: five wells were in the Mojave Desert near Palmdale, California; three were near Limekiln Valley, south of Hollister, California; and two wells were at Monticello Reservoir, northwest of Columbia, South Carolina. The wells were continuously logged using an ultrasonic borehole televiewer (described below), and the fracture orientations and distribution as a function of depth were determined. This data was evaluated to determine (1) whether statistically significant fracture orientations are to be found in the total fracture population, (2) whether the number of fractures or the orientation of significant concentrations varies with depth, (3) whether the fracture frequency and orientation vary from location to location in a given region, and (4) what relation, if any, can be found between the observed fractures and what is known about the regional stress field and the geologic history.

\section{TEChNIQUe}

The borehole televiewer (manufactured by Simplec Manufacturing Co. under license of Mobil Oil Corp.) is a rotating acoustic transducer emitting pulses focused in a $3^{\circ}$ beam at a rate of 180 times per second [Zemanek et al., 1970]. The transducer rotates at three revolutions per second and moves vertically in the hole at a speed of $2.5 \mathrm{~cm} / \mathrm{s}$. The amplitude of the reflected signal is plotted as brightness on a three-axis oscilloscope as a function of the beam azimuth and vertical position in the hole. The scope trace is triggered at magnetic north by a flux gate magnetometer in the tool. Essentially, the smoothness of the borehole wall is mapped. Where the smoothness of the borehole wall is perturbed by a planar features such as a fracture, a dark sinusoidal pattern is seen (see Figure 1). Resolution of the tool depends upon hole diameter, wall conditions, reflectivity of the formation, and acoustic impedance of the well bore fluid. The wall condition is the most important 


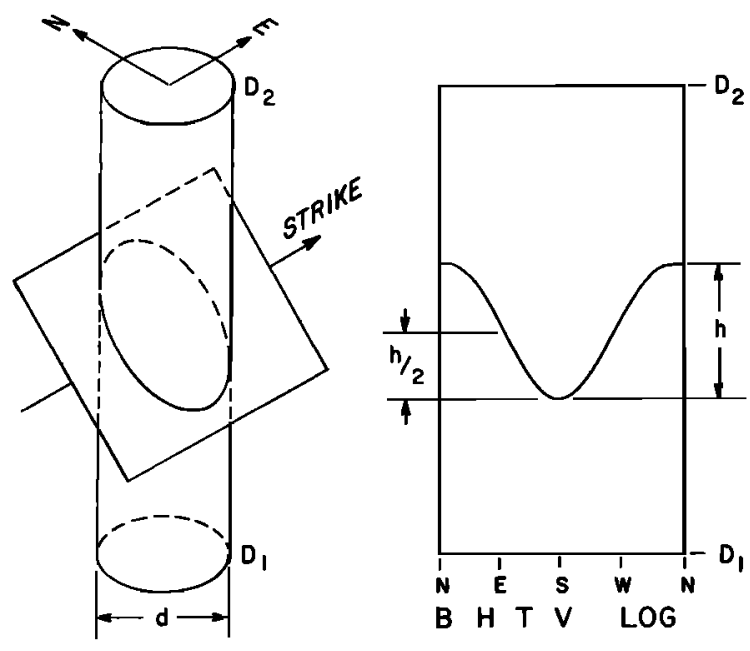

Strike : Orientation of midpoint between peak and trough $($ of $h / 2$ )

Dip : $\tan ^{-1} \mathrm{~h} / \mathrm{d}$

Fig. 1. Isometric sketch of fracture or bedding plane intersecting borehole at moderate dip angle and corresponding Borehole Televiewer $\log$ [after Zemanek et al., 1970, Figure 7].

factor as a rough well bore makes detection of fine features quite difficult. Except for highly fractured intervals, the conditions in the Mojave and Monticello wells were nearly ideal, and all fractures were apertures of more than a few millimeters were probably detected. The conditions in the Limekiln Valley wells were highly variable. In heavily fractured, poor picturequality intervals, only a subset of the total fracture population could be analyzed. All of the wells were drilled as undeviated, vertical holes. Deviation surveys run in the later wells confirmed that the wells were essentially vertical.

As an example, Figure 2 presents televiewer pictures of a $15-\mathrm{m}$ vertical section of a well in the Mojave desert. The interval from about 168 to $172 \mathrm{~m}$ in Figure 2 is one in which numerous single subparallel fractures are found. From about 173 to $175 \mathrm{~m}$ there is a relatively unfractured interval, although several small fractures might be present near $174.5 \mathrm{~m}$. From about 175 to $178 \mathrm{~m}$ is an interval in which a few distinct, parallel fractures are found with large apparent aperture. From 178 to $183 \mathrm{~m}$, two more fractures similar to those just above are seen as well as several finer scale features which also appear to be fractures.

Knowing the well diameter the dip of these fractures may be calculated by measuring the peak to trough amplitude of the sinusoids. The fracture strike is taken to be in the direction of the midpoint between peak and trough (Figure 1). The test wells were drilled with a diameter of approximately $15 \mathrm{~cm}$ so that the circumference (horizontal scale) is about $50 \mathrm{~cm}$. Thus, there is greater than $3: 1$ horizontal exaggeration in the pictures and as a result, fractures with dips of less than $5^{\circ}$ appear to be horizontal. Apparently low-dipping fractures (such as those in the first few meters of Figure 2) actually dip at least $10^{\circ}-15^{\circ}$.

Televiewer surveys were run in each well from total depth (TD) to the top of the water column or the bottom of casing, in either case, usually to within several meters or tens of meters of the surface. Only those features for which the sinusoidal signature could be resolved were picked as fractures.

There are two major limitations in the analysis of fracture orientation from televiewer data. First, with the televiewer, only the orientation of a small portion of a fracture plane is actually observed. On a large scale, many fractures may appear planar, but when restricted to viewing only small portions of the entire fracture, variations of strike and dip by as much as $10^{\circ}$ may be apparent. Thus, in trying to determine preferred fracture orientation, data from televiewer surveys may result in more scatter and lower levels of statistical significance for preferred orientations than would be found in surveys which consider larger portions of the fractures. The second problem is that nearly vertical fractures are not often intersected by vertical wells. Thus, there is a bias in the method as vertical fractures are not sampled.

To evaluate the distribution of fracture orientations, poles to fracture planes for all dipping fractures in each well were plotted on a lower hemisphere, equal-area projection. To obtain an estimate of the statistical significance of these pole groupings (and thus to arrive at an estimate of the preferred fracture orientations), orientation-density diagrams were prepared using a method described by Kamb [1959]. The pole densities were contoured in intervals of $2 \sigma$, where $\sigma$ is the standard deviation of the total number of points in a given area under random sampling. The expected density $E$ for no preferred orientation is $3 \sigma$. The standard deviation and the sampling area used in preparing these diagrams are both determined by a statistical relation based upon the number of poles plotted. The number of poles $N$, the sample area $A$, given as a fracture of the total area of the hemisphere, the expected density $E$, and the standard deviation $\sigma$ are given for each plot. Observed densities that differ from $E(3 \sigma)$ by more than 2 or 3 times the standard deviation (i.e., $>6 \sigma$ ) are likely to be significant, particularly if the higher densities are clustered in one section of the diagram. An example of the method is presented in Figure 3; the number of poles $N$ is 165 , the sample area $A$ is 0.05 , the expected density $E$ is 8.6, and the standard deviation $\sigma$ is 2.9. As shown in Figure $3 b$, the only statistically significant pole concentrations in Figure $3 a$ are two clusters with mean strikes and dips of about $\mathrm{N} 20^{\circ} \mathrm{W}, 63^{\circ} \mathrm{SW}$, and $\mathrm{N} 52^{\circ} \mathrm{W}, 55^{\circ} \mathrm{NE}$.

\section{DATA AND INTER PRETATION}

\section{Mojave Desert Wells}

Five wells were drilled in the western Mojave desert as part of an in situ stress measurement program along the locked portion of the San Andreas fault in southern California. The sites lie along the part of the fault that last ruptured in the 1857 Fort Tejon earthquake. Throughout the western Mojave desert, Tertiary formations rest unconformably upon a surface of pre-Tertiary crystalline rocks that underwent deep erosion during late Cretaceous and early Tertiary time [Dibblee, 1967]. In middle to late Miocene time the Mojave block was deformed primarily by normal faulting along northwest trending faults [Dibblee, 1967]. Geologic and paleomagnetic studies indicate that as much as $10 \%$ north-south shortening of the wedge between the Garlock and San Andreas faults may have occurred during the Pliocene and Quaternary [Ponti and Burke, 1979]. This shortening has been accommodated by strike slip faulting on northwest striking faults, thrust faulting on eastwest trending faults, folding, and possible block rotation. The nature of the deformation is consistent with an applied north- 


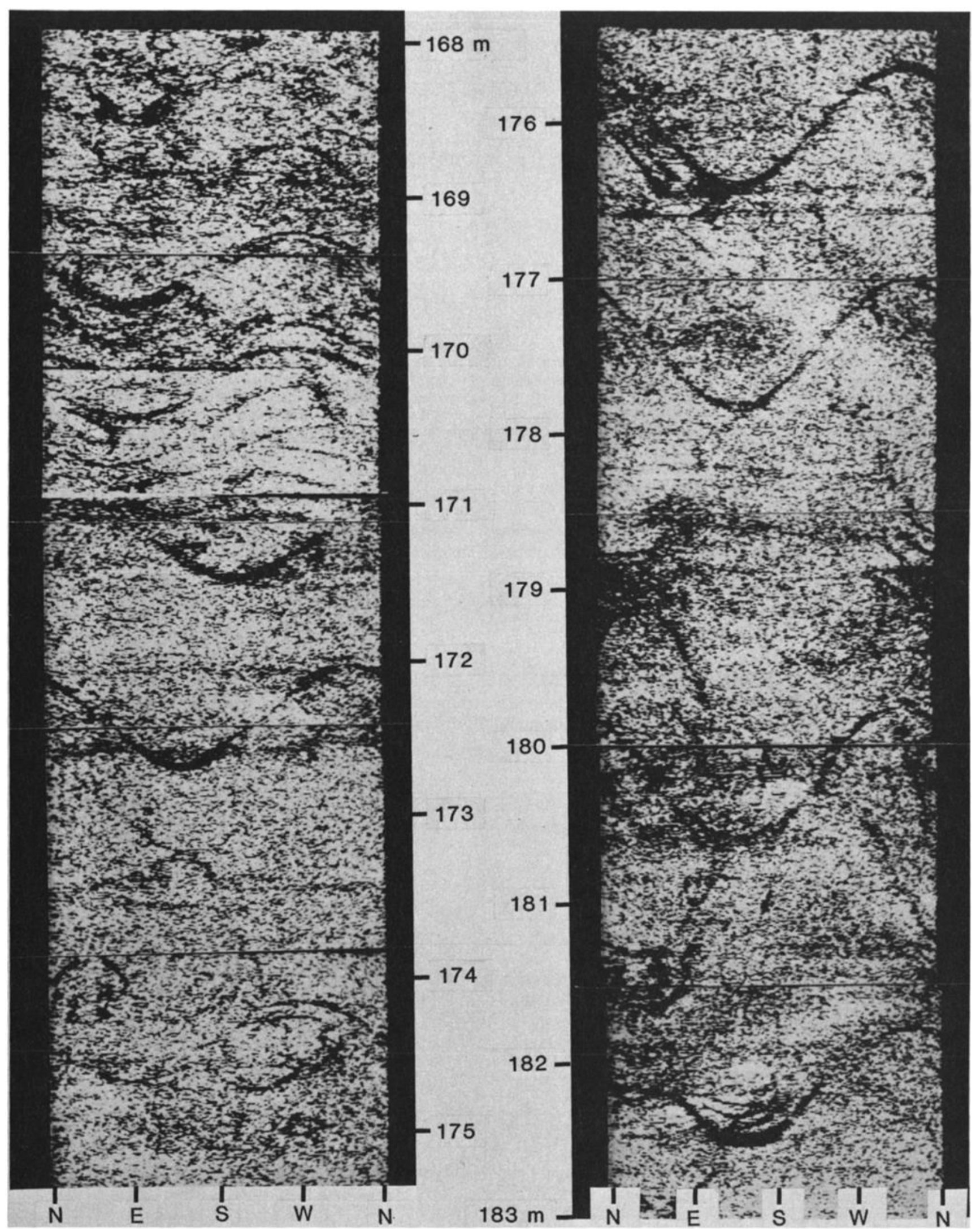

Fig. 2. Televiewer pictures for $15.2 \mathrm{~m}$ of well in two 7.6-m sections. Top of sequence is at upper left, bottom at lower right. Numerous fractures are present which appears as dark sinusoidal bands. 

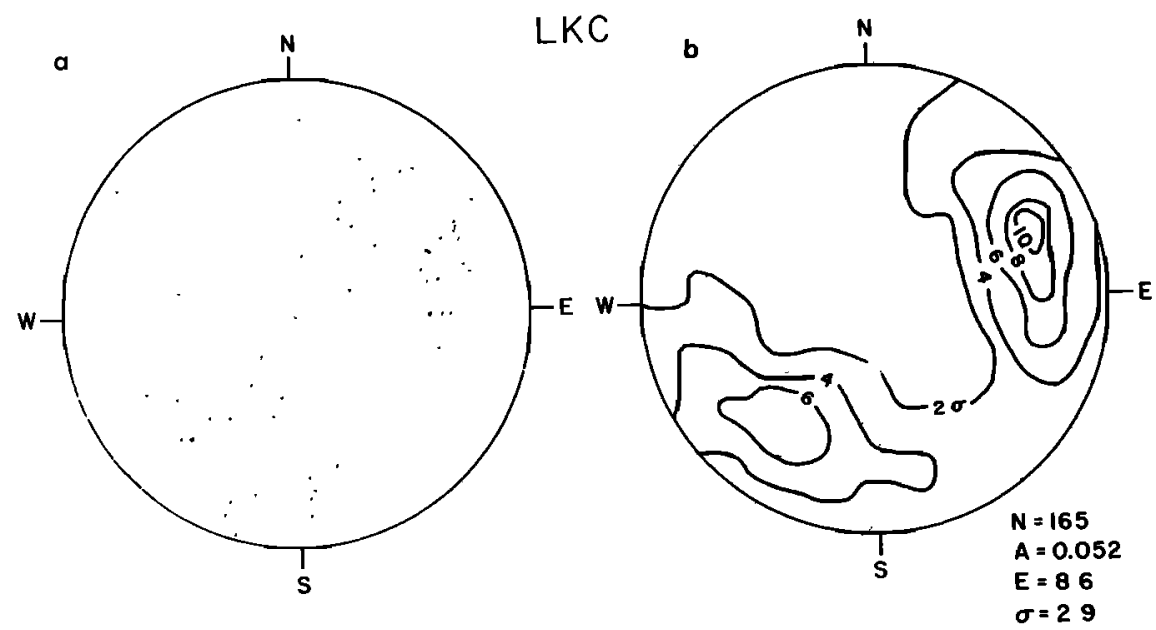

Fig. 3. (a) Lower hemisphere equal-area stereographic projection of fracture poles encountered in well LKC. (b) The corresponding orientation-density diagram. The standard deviation, $\sigma=2.9$, and the sampling area, $A=0.05$, are determined by the number of fractures, $N=165$, using the method of $K a m b$ [1959]. A random distribution of poles would yield pole densities between $2 \sigma$ and $4 \sigma$. Pole densities greater than $6 \sigma$ represent statistically significant preferred fracture orientations. Two significant pole clusters are shown here: a north-northwest striking southwest dipping cluster with maximum contour of $10 \sigma$ and a northwest striking, northeast dipping cluster with maximum contour of $6 \sigma$.

south compression. Geodetic measurements [Savage and Prescott, 1979; Lisowski and Savage, 1979; Prescott and Savage, 1976; Thatcher, 1976] indicate that present deformation in the western Mojave near Palmdale has a direction of maximum shortening of $\mathrm{N} 10^{\circ}-15^{\circ} \mathrm{W}$ and a direction of maximum extension of about $\mathrm{N}^{\circ} 5^{\circ}-80^{\circ} \mathrm{E}$. This deformation field is basically consistent with the in situ stress field orientations determined by hydraulic fracturing in two of the wells considered in this study, Mojave 1 and 2 [Zoback et al., 1980].

Four of the wells in the western Mojave desert comprise a north-northeast trending profile running across the San Andreas fault from the foothills of the San Gabriel Mountains near Valyermo to Adobe Mountain in the western Mojave desert (Figure 4).

Well 1 was drilled on the north limb of a large syncline $2 \mathrm{~km}$ southwest of the San Andreas fault and between the San Andreas and Punchbowl faults (Figure 4). Well 1 is the only well in this study which did not penetrate crystalline rock. The data and analysis are presented here for completeness. The axis of the syncline strikes $N 70^{\circ} \mathrm{W}$ and plunges to the west. At the well site the dip of the north limb was approximately $45^{\circ}-50^{\circ}$ to the southwest. The well was drilled to a depth of $245 \mathrm{~m}$, entirely through the upper Miocene Punchbowl formation. Here the Punchbowl formation consists of massive, cross-bedded, coarse

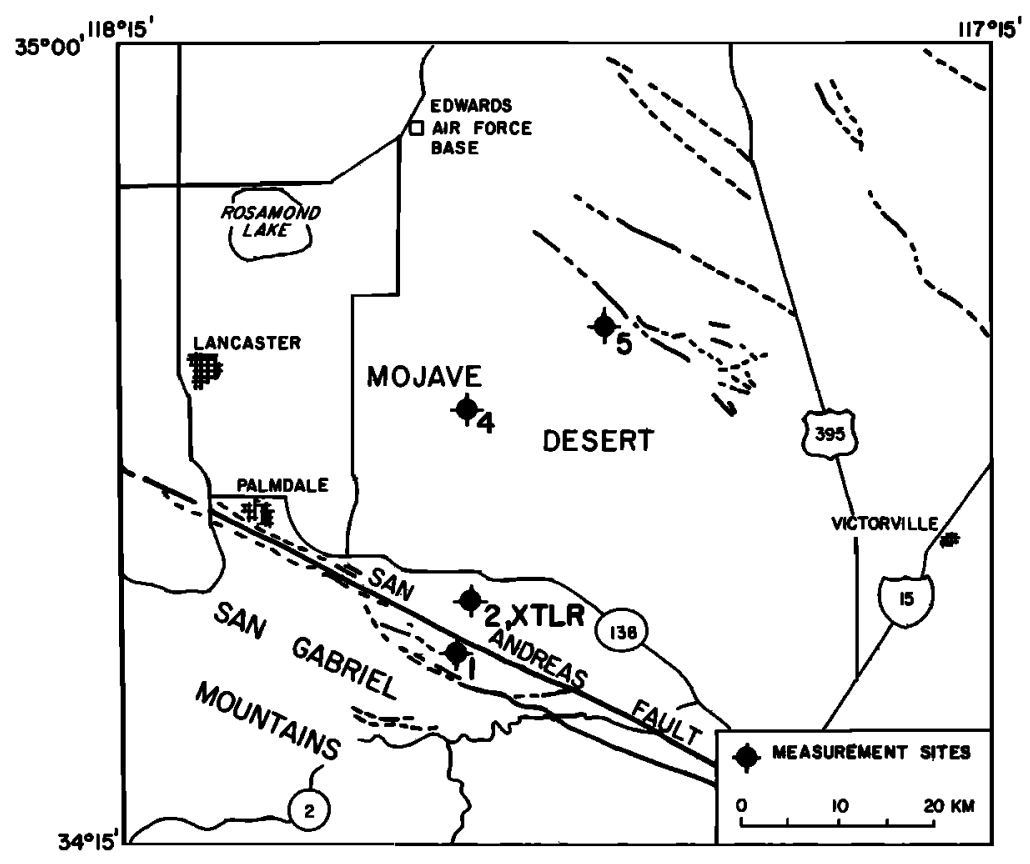

Fig. 4. Map showing location of wells in the western Mojave desert, California. Well 1 is about $2 \mathbf{k m}$ southwest of the San Andreas fault and was drilled entirely through the Miocence Punchbowl sandstone. Wells 2, 4, 5, and XTLR are 4, 22, 34, and $\mathbf{4 k m}$, respectively, northeast of the San Andreas fault. All were drilled in Mesozoic quartz monzonite which is part of the suite of Mesozoic intrusives which form the basement of much of the western Mojave. 
terrestrial sandstone with large lenses of pebble and cobble conglomerate [Noble, 1954]. At surface outcrops the formation is relatively unfractured, although there are bedding plane fractures spaced at 1- to 3-m intervals and some vertical joints with locally varying attitudes, spaced at 3- to 7-m intervals [Sbar et al., 1979].

Wells 2, 4, 5, and XTLR were drilled at buttes located 4, 22 , 34 , and $4 \mathrm{~km}$, respectively, northeast of the San Andreas fault (Figure 4). These wells were drilled entirely in quartz monzonite to depths of $257,230,239$, and $869 \mathrm{~m}$, respectively. The quartz monzonite buttes are part of the suite of Mesozoic intrusives which form the basement of much of the western Mojave. Horizontal and steeply dipping fractures and joints were observed in outcrops at these sites. The buttes are apparently composed of slightly more siliceous material than the surrounding basement, and are thus more resistant to erosion (D. B. Burke, personal communication, 1980).

The rock penetrated by the Mojave wells was found to be highly fractured. Figure 5 contains frequency plots showing the number of fractures per meter as a function of depth for each well, and Figure 6 contains plots of the cumulative number of fractures in each well as a function of depth. The number of fractures observed in well 1 , drilled in sandstone, is significantly less than that observed in the wells drilled in quartz monzonite. The number of fractures per meter is not uniform throughout each well. Fractures often occur in relatively dense clusters, as at about $55 \mathrm{~m}$ and $115-125 \mathrm{~m}$ in Mojave 4 (Figure 5). These fractured intervals appear in Figure 6 as steeper portions of the cumulative fracture curve. The cumulative fracture curve for Mojave 2 appears to flatten somewhat at depths greater than $160 \mathrm{~m}$, implying a decrease in the fracture density. In the other wells, the curves indicate that the fracture density may be decreasing with depth below $150-200 \mathrm{~m}$, but there is only a very moderate trend to lower fracture density with depth. Also, note that in the upper $150 \mathrm{~m}$ the number of fractures encountered in Mojave 2, 4, and 5 are similar. The data show no

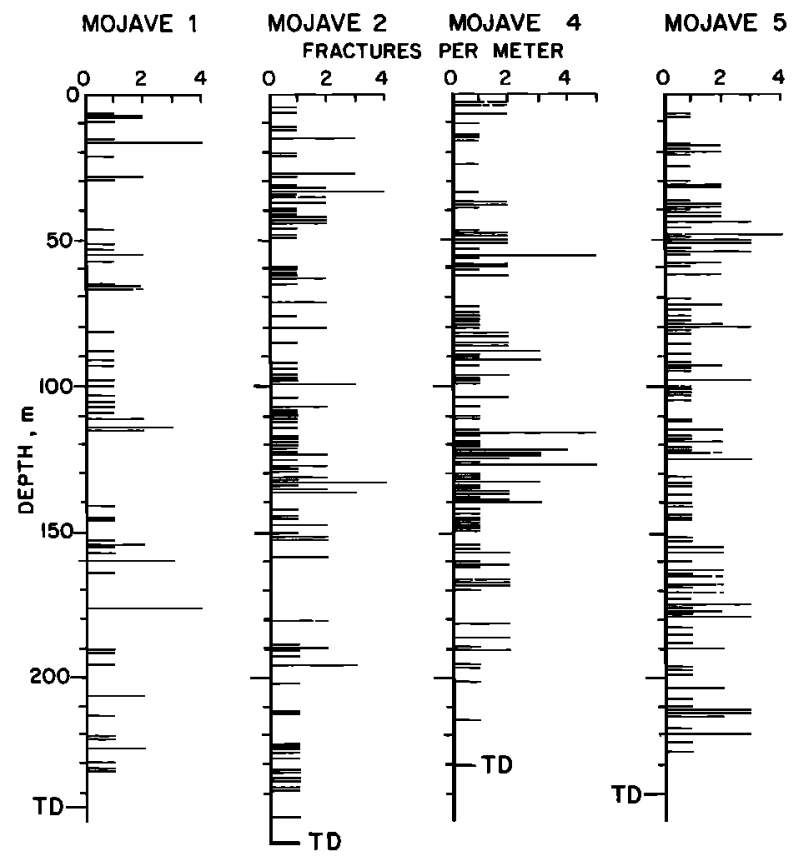

Fig. 5. Frequency plot of the number of fractures per meter as a function of depth in the Mojave wells 1,2,4, and 5.

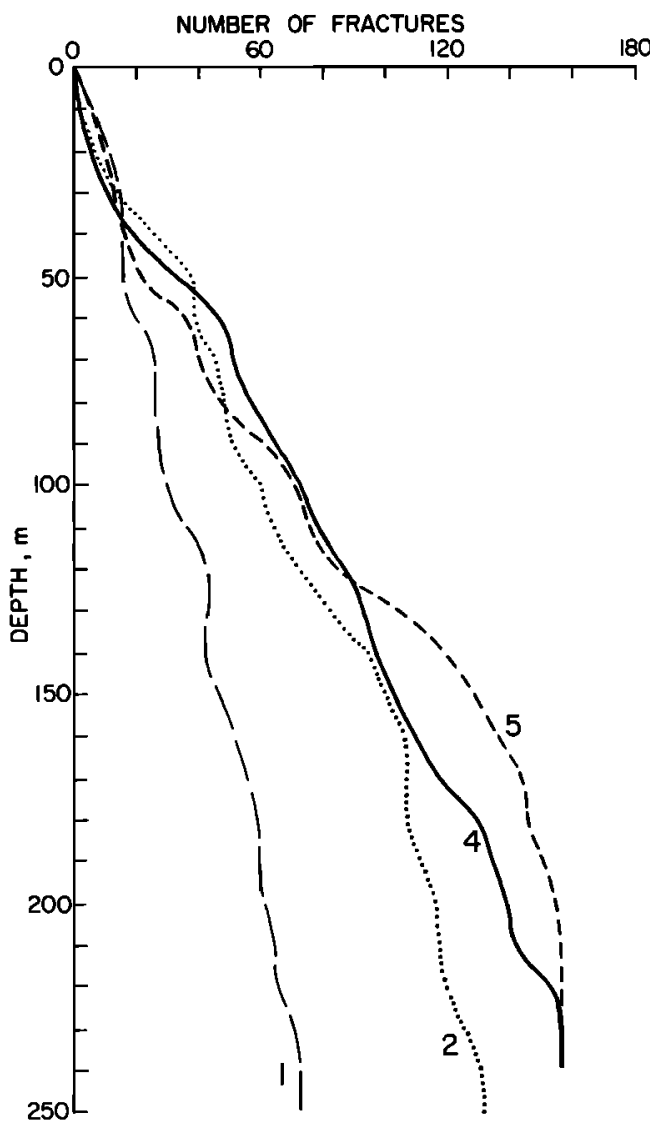

Fig. 6. Cumulative number of fractures plotted as a function of depth for the Mojave wells. The sandstone encountered in Mojave 1 is significantly less fractured than the granite encountered in wells 2,4 , and 5 . In general, only a slight decrease in the number of fractures with increasing depth is observed.

tendency for the fracture density to increase as the San Andreas fault is neared.

Poles to all of the dipping fractures are shown in Figure $7 a$. Figure $7 b$ contains the orientation-density plots derived from the pole distributions. At least two significant maxima are observed in the density plots for each well. For all wells, the secondary maxima are significant at only the $6 \sigma$ level. For wells 2 and 4 the primary maxima also barely exceed the $6 \sigma$ level.

In Mojave 1 the predominant fracture set $(>10 \sigma)$ strikes $\mathrm{N} 20^{\circ}-30^{\circ} \mathrm{W}$ and dips $35^{\circ}-40^{\circ}$ to the southwest. A second cluster $(>6 \sigma)$ with fractures striking slightly east of north is also present. Bedding planes, which would strike about $\mathrm{N} 70^{\circ} \mathrm{W}$ and dip about $45^{\circ}-50^{\circ} \mathrm{SW}$, were not observed. In Mojave 2 a broad cluster $(>6 \sigma)$ of northwesterly striking, southwest dipping $\left(\sim 50^{\circ}\right)$ fractures are found. In Mojave 4, fracture sets trending $\mathrm{N} 35^{\circ}-55^{\circ} \mathrm{E}$ and dipping $50^{\circ}-60^{\circ}$ to the northwest and southeast are found at the $6 \sigma$ level. Most fractures in Mojave 2 and 4 appear to be randomly oriented, with minor significant maxima. In contrast, in Mojave 5 a fracture set striking about $\mathrm{N} 80^{\circ} \mathrm{E}$ and dipping steeply $\left(\sim 60^{\circ}\right)$ to the southeast is extremely pronounced $(>16 \sigma)$. A second set of fractures $(>6 \sigma)$ is also observed in Mojave 5 striking northwest and dipping to the northwest. Note that the majority of observed fractures dipped from $40^{\circ}$ to $70^{\circ}$. Very few horizontal fractures were observed in these wells: 3 in Mojave 1, 2 in Mojave 2, 3 in Mojave 4, and 4 in Mojave 5.

Fractures occurring below a depth of $137 \mathrm{~m}$ were analyzed separately to test for depth dependence in the fracture orienta- 

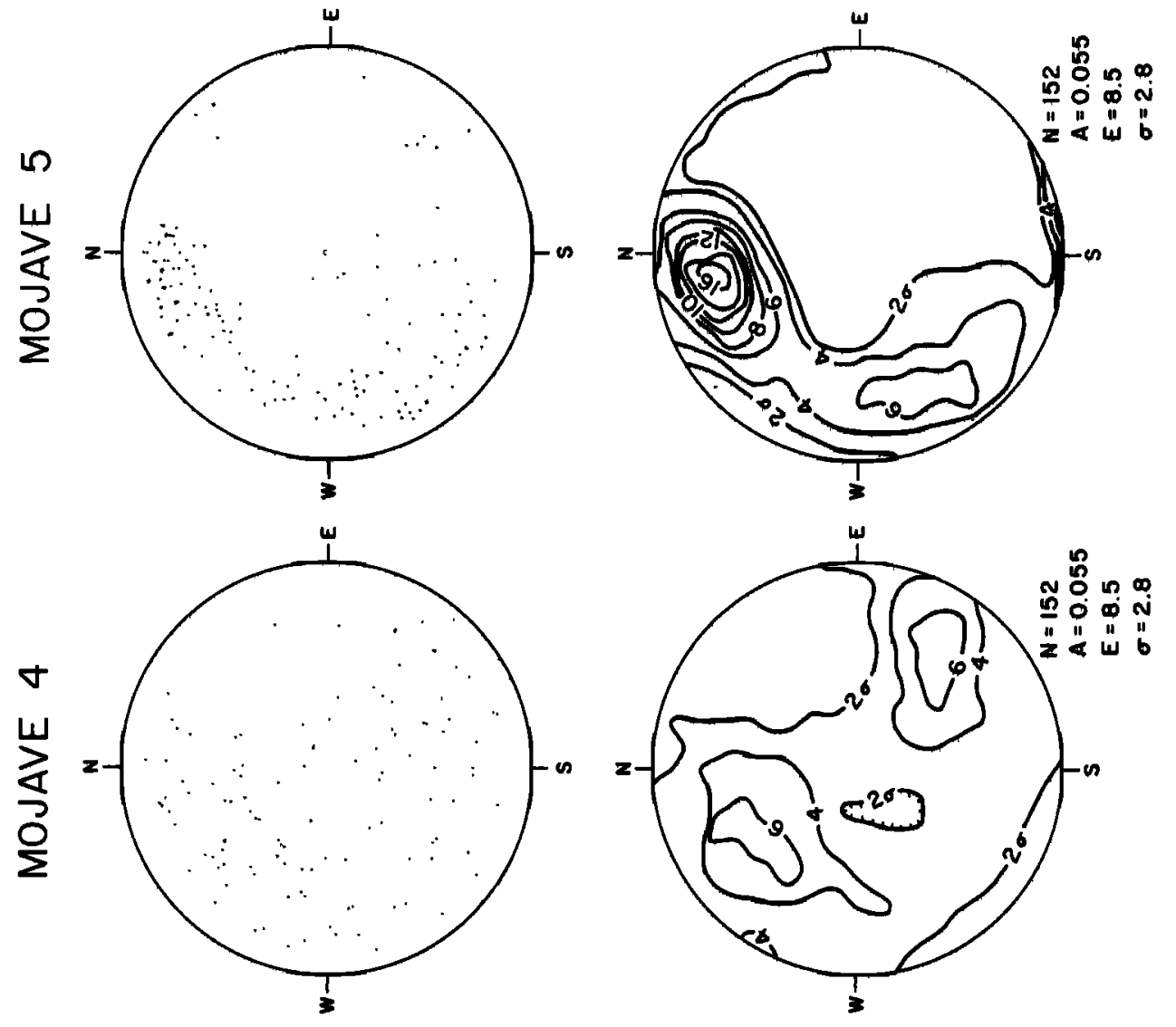

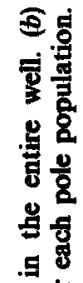
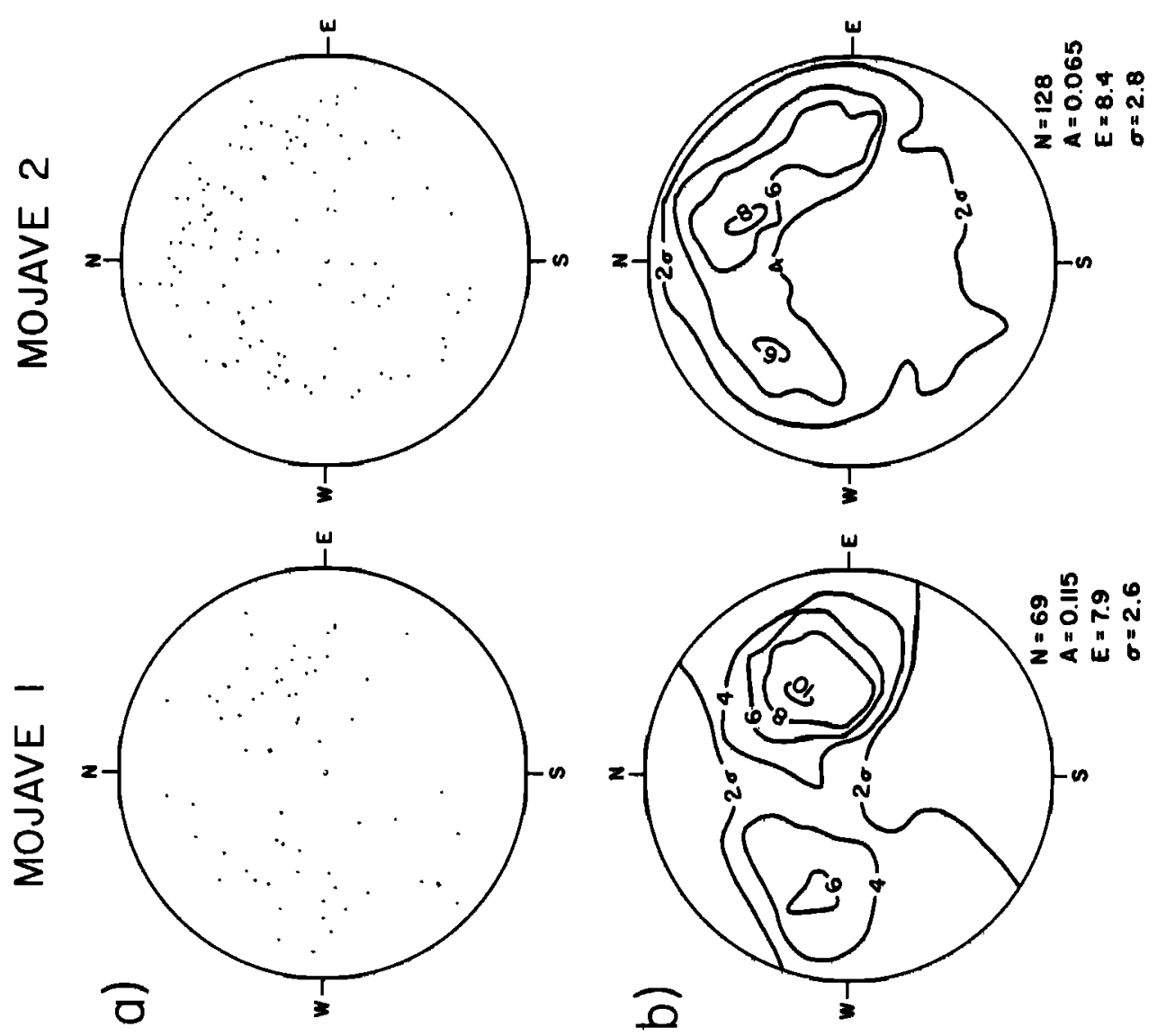

8

$\checkmark$ 宸 
tion. Poles and density plots for the fractures found in these intervals are shown in Figure 8. A comparison of Figures 7 and 8 shows that each of the maxima present below $137 \mathrm{~m}$ also appears when fractures in the entire well are considered. Thus, the fracture patterns in the deeper intervals are basically subsets of the patterns found throughout the wells.

Well XTLR was drilled at the same site as Mojave 2. The results of fracture studies performed in this well are shown in Figures 9 and 10. From Figure 9 it can be seen that the quartz monzonite was highly fractured throughout. Note that only a slight decrease of fracturing with depth was observed. The greatest decrease in fracture density was found at about $140 \mathrm{~m}$, as in the shallow wells. There is, however, no strong trend toward unfractured rock with depth.

One significant $(>14 \sigma)$ cluster of poles was found in well XTLR striking N $5^{\circ}-25^{\circ} \mathrm{W}$ and dipping about $60^{\circ} \mathrm{SW}$. A comparison of Figures 7 and 10 shows that the fracture orientations found in Mojave 2 and XTLR are nearly the same. With the increased depth and number of fractures in XTLR, the level of significance of this pole cluster increased substantially.

Deep measurements of the stress field in XTLR [Zoback et al., 1980] indicate that the minimum horizontal stress is the minimum principal stress below a depth of about $300 \mathrm{~m}$. Below this depth strike slip faulting would be preferred. To test whether the change from a thrust-type environment to a strike slip environment affected the fracture orientations, the distribution of those fractures found below $300 \mathrm{~m}$ in XTLR was considered (Figure 11). One significant $(>14 \sigma)$ cluster was found. The orientation of this cluster is indistinguishable from the preferred fracture orientation found above $300 \mathrm{~m}$, in the entire well, and from Mojave 2. The level of significance for this fracture orientation is greatest when the deep fracture data are included. The primary effect seen in the near-surface intervals seems to be the addition of randomly oriented fractures which served to decrease the significance of the shallow interval clusters. Therefore, the change in minimum stress orientation produced no noticeable change in the observed fracture distribution.

\section{Monticello Reservoir, South Carolina}

Two approximately 1-km deep wells were drilled near Monticello Reservoir, Fairfield County, South Carolina (Figure 12). The well sites are in an area underlain by a complex series of almandine-amphibolite facies, metamorphic rocks, and granitic intrusives of the Charlotte Belt lithologies of the Piedmont Province [Dames and Moore, 1974]. These consist of interlayered and folded gneisses, amphibolite, and schist, all of which have been intruded by plutons of granite to granodiorite composition. The following description of the geologic history of the region has been synthesized from the work of Overstreet and Bell [1965], Fisher et al. [1970], and Dames and Moore [1974].

Most of the metamorphic rocks presently exposed in the Piedmont were originally deposited as a thick sequence of shale, siltstone, volcanic tuff, etc. in the 'Appalachian geosyncline' between 250 and $600 \mathrm{~m}$. y. ago. Episodes of folding, regional metamorphism, and igneous intrusion apparently followed each of three long sedimentation intervals. At the end of the late Paleozoic, the final depositional period, the previously formed metamorphic rocks and the unmetamorphosed sediments experienced regional metamorphism. During this time the Piedmont was uplifted, accompanied by faulting, folding, and the intrusion of discordant plutons. Also during this period, northwestward directed overthrusting occurred on a major scale in the southern Appalachians.
By mid-Triassic much of the Piedmont had been worn down to a broad peneplain which truncated the exposed complex rock structures. Subsequent re-elevation of the region was accompanied by the formation of northeast-southwest trending structural troughs. These troughs are generally parallel to regional northeast-southwest trending Appalachian structures. Further uplift in Late Triassic or Early Jurassic time was accompanied by the emplacement of numerous northwestsoutheast trending diabase dikes intruded along preexisting fractures. After another erosional cycle, during which the Piedmont was again reduced to a peneplain, continental uplift elevated the region now occupied by the Appalachians and adjacent Piedmont areas. Since the Jurassic, the region has undergone weathering, erosion, and deposition without any major tectonic disturbances.

The two wells, Monticello 1 and 2, were drilled to depths of 1100 and $1203 \mathrm{~m}$, respectively, as part of a program to study the stresses associated with induced seismicity at Monticello Reservoir. Both wells were drilled in intrusive granodiorite bodies of late Paleozoic age. The drill site for Monticello 1 was located on the top of a broad ridge west of the center of the reservoir. Monticello 2 was drilled within $1 \mathrm{~km}$ downstream of the dam which impounds the reservoir. The two wells are about $5 \mathrm{~km}$ apart. A northward projection of several kilometers places the north-south trending, steeply dipping, dip slip (down to the east) Wateree Creek fault near and to the west of the location of Monticello 2 [Secor, 1980].

Borehole televiewer records were obtained for the total depth of each well. The well conditions were excellent, and the recorded data quality was generally very good.

The results of the fracture surveys are presented in Figures 13 and 14. Figure 13 shows the number of fractures as a function of depth in each well. Figure 14 shows poles to fracture planes and orientation-density plots.

The data show that the state of natural fracturing in the two wells is significantly different. The total number of fractures in Monticello 2 is approximately 3 times that in Monticello 1 (Figure 13). Fractures in Monticello 1 were found to occur mostly in discrete intervals, such as at $140,190,300$, and $580 \mathrm{~m}$ within relatively unfractured rock. In contrast, the granodiorite encountered in Monticello 2 was highly fractured, particularly from the surface to about $275 \mathrm{~m}$ and from about 460 to $510 \mathrm{~m}$. Due to the highly fractured nature of the rock, small discrete fracture zones, as found in Monticello 1, are not as apparent in Monticello 2. The lowest fracture density in Monticello 2 is found from about 510 to $750 \mathrm{~m}$ and is similar to the fracture density found in Monticello 1 at the same depth. Below $750 \mathrm{~m}$, a slight increase in the fracture density is observed in Monticello 2. It is interesting to note that the slope of the cumulative fracture curve for Monticello 2 in the intervals $275-460 \mathrm{~m}$ and $750 \mathrm{~m}-\mathrm{TD}$ are about the same and the segments are nearly colinear. In the interval from 460 to $750 \mathrm{~m}$, strain energy release was apparently concentrated in the densely fractured zone at $460-510 \mathrm{~m}$. As a result, the fracture density from 510 to $750 \mathrm{~m}$ is the lowest found in this well. In neither well is there an appreciable decrease in the number of observed fractures with depth.

Twenty-six of the 147 fractures in Monticello 1 and 65 of the 439 fractures in Monticello 2 were horizontal. This is by far the highest density of horizontal fractures of any of the data sets. Horizontal fractures were found throughout each well; however, about half of each total was found in the upper $300 \mathrm{~m}$ of the well (Figure 15). In both wells, several horizontal fractures were found at depths greater than $1 \mathrm{~km}$. In addition, the density 

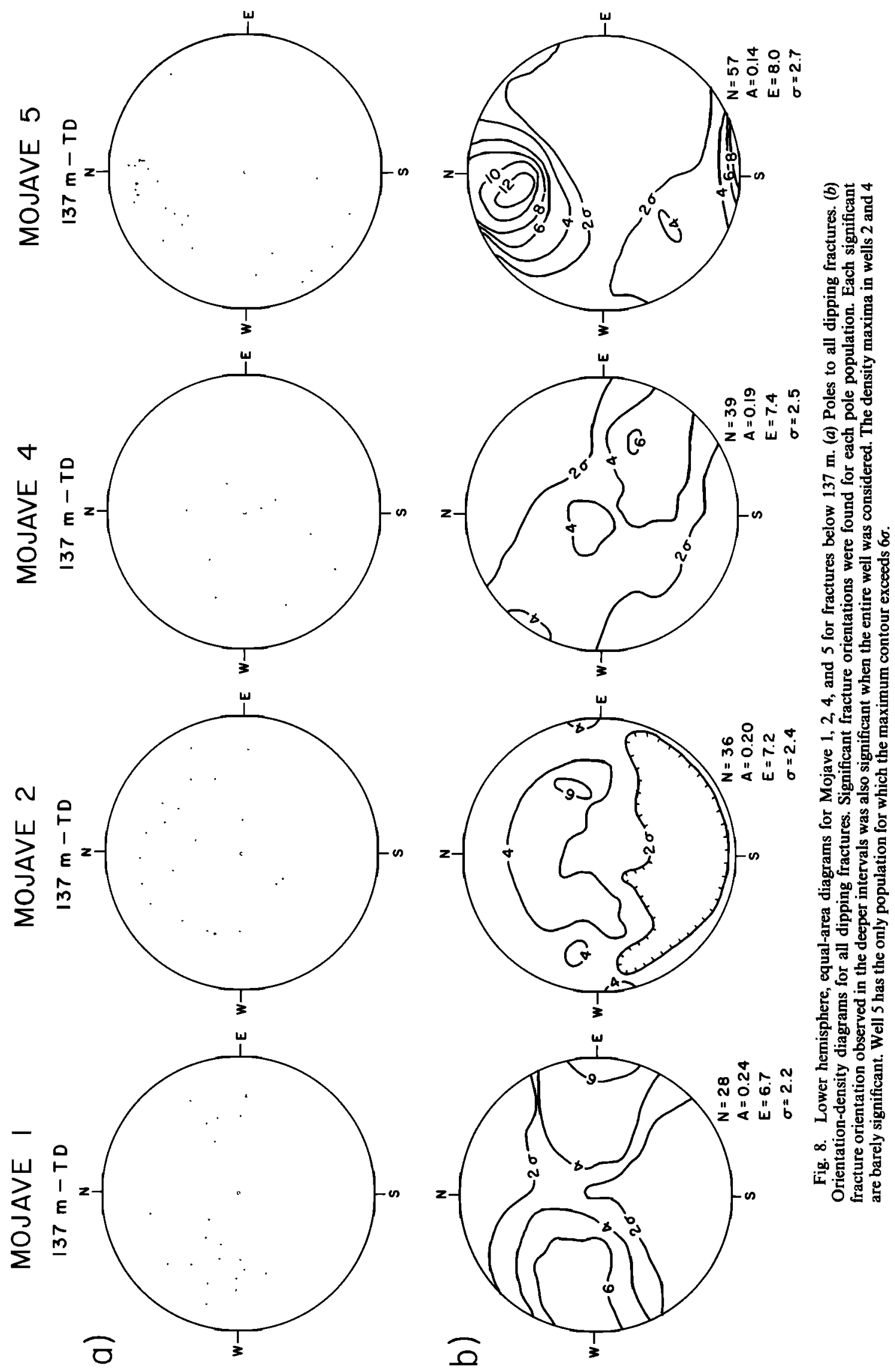


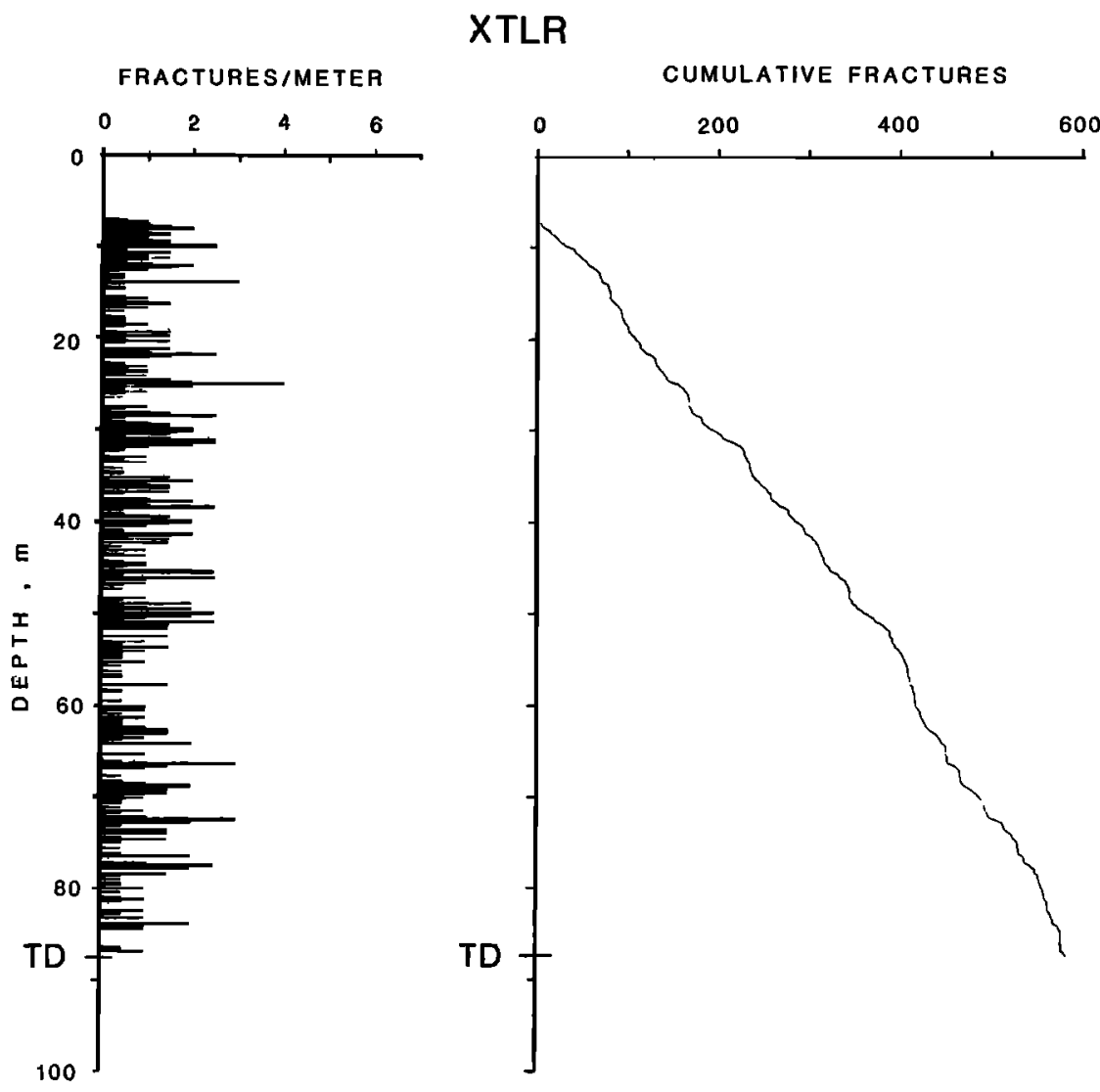

Fig. 9. Frequency plot of number of fracture plotted as a function of depth for well XTLR (left) and cumulative number of fractures plotted as a function of depth for XTLR (right).

of horizontal fractures is relatively high in Monticello 2 in the interval $400-500 \mathrm{~m}$. The presence of these horizontal fractures may be due to decreased confining stresses as a result of the post-Jurassic erosional history of the area.

The orientation-density plot for Monticello 1 (Figure 14) shows two small significant maxima (contours $>6 \sigma$ ) with approximate orientations of strike $\mathrm{N} 45^{\circ} \mathrm{E}$, dip $60^{\circ} \mathrm{E}$ and strike
$\mathrm{N} 50^{\circ} \mathrm{W}$, dip $25^{\circ} \mathrm{W}$. For Monticello 2, there is one extremely dense cluster of poles (maximum contour $>12 \sigma$ ) with a strike of about $\mathrm{N} 5^{\circ} \mathrm{E}$ and $\operatorname{dip} 70^{\circ} \mathrm{E}$.

In addition to the major differences in fracture orientation found within a horizontal distance of only $5 \mathrm{~km}$, there were major differences in fracture orientation vertically in each well. In Monticello 1 this difference is shown in Figure 16 in which
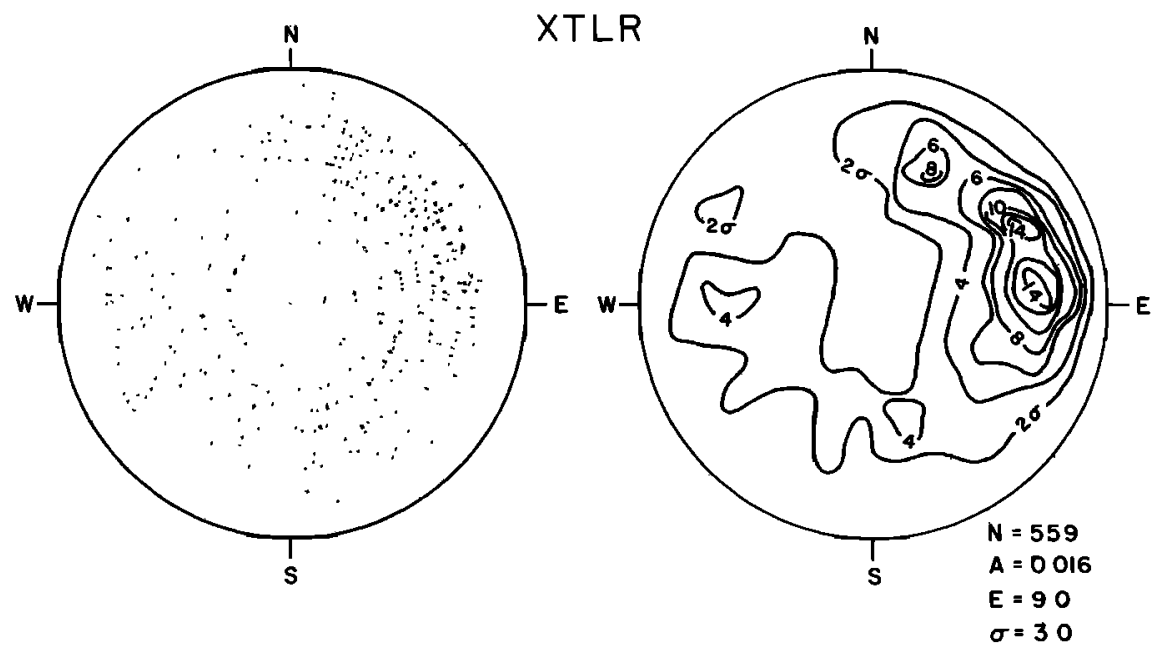

Fig. 10. Lower hemisphere, equal-area plots of poles to all dipping fractures in well XTLR (left) and orientation-density diagram for all dipping fractures (right). The maximum contours (14 $\sigma$ ) indicate that the preferred fracture orientation strikes north-northwest and dips steeply to the southwest. This pole distribution compares favorably, particularly in the deeper interval, with that found in Mojave 2, which was drilled at the same site as XTLR. The strike of this significant fracture orientation is parallel to the direction of the maximum regional compressive stress, possibly implying that these fractures are being held open like tensile features. 


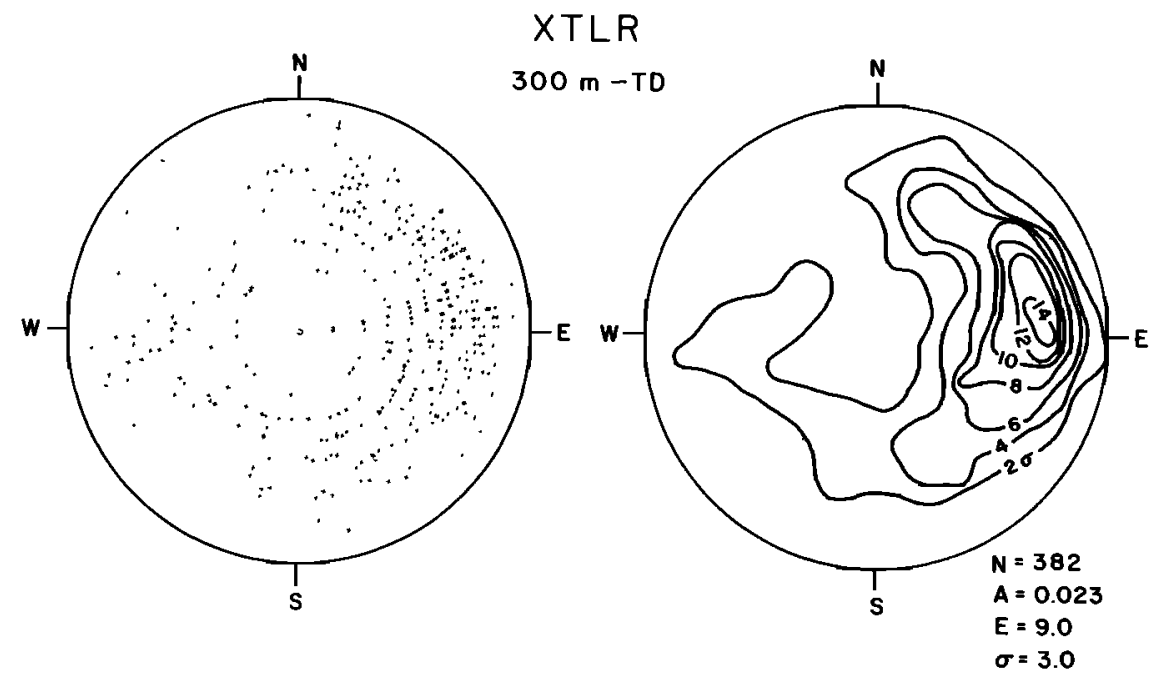

Fig. 11. Lower hemisphere, equal-area stereographic pole diagrams for all dipping fractures below $300 \mathrm{~m}$ in XTLR.

orientation-density plots are shown for the intervals surface$305 \mathrm{~m}, 305-610 \mathrm{~m}$, and $610 \mathrm{~m}-\mathrm{TD}$. In the upper zone (surface$305 \mathrm{~m}$ ) one significant cluster with northwest strike and southwest dip is apparent, a subset of the cluster found when all fractures encountered in the well were considered. In the middle zone (305-610 m), a northeast striking, southeast dipping cluster is apparent. This cluster is also apparent when all fractures are considered. In the pole density plot for the bottom third of the well $(610 \mathrm{~m}-\mathrm{TD})$, the distribution is seen to be essentially random. In Monticello 2 (Figure 17) the fractures in the upper zone form two significant clusters $(>6 \sigma)$ : one striking approximately north-south and dipping to the east, and one striking east northeast and dipping gently to the southeast. In the lower interval $(610 \mathrm{~m}-\mathrm{TD})$ there is a dense cluster $(>16 \sigma)$ of fractures striking north-south and dipping to the east. This north-south striking set is prominent when the fractures as a whole are considered. The fracture cluster found in the interval 305-610 $m$ has a strike which differs by about $60^{\circ}$ from that found in the rest of the hole. This group of fractures is the west-northwest trending, northeast dipping set responsible for the extended lobe on the density plot for the entire well (Figure 14).

Secor [1980] presents the results of joint studies made at surface outcrops near Monticello Reservoir. At outcrops within a few kilometers of the well sites, fracture distributions similar to those found in both Monticello 1 and 2 were found. Secor concluded that there was little regional consistency to the orientation of the major joint sets. The marked difference we have observed in the two wells seems to support this conclusion. Surface fractures were also studied on the cleared bedrock surface at the site of the Virgil C. Summer Nuclear Station [Dames and Moore, 1974]. This site is about $6 \mathrm{~km}$ southeast of the Monticello 1 site and $1 \mathrm{~km}$ east of Monticello 2. Poles to 247 fractures with no observed shear displacement across their faces and to 85 fractures which exhibited either shear displacement or hydrothermal alteration were plotted [Dames and Moore, 1974]. In both cases, a pole density maximum occurred for planes striking about $\mathrm{N} 44^{\circ} \mathrm{E}$, dipping more than $60^{\circ} \mathrm{SE}$. This orientation is very similar to one of the maxima found in Monticello 1. However, other maxima in the surface data, such as a northeast trending, northwest dipping set, are not apparent in data from either well. There is no surface indication of the pronounced north-south trending, eastward dipping set of fractures which is found in Monticello
2, but as shown in Figure 16, this fracture set is most pronounced at depths greater than $600 \mathrm{~m}$. However, this orientation is similar to that of the Wateree Creek fault, where studied several kilometers south of the Monticello 2 site.

It has been noted that the fracture distribution in the interval $305-610 \mathrm{~m}$ in Monticello 2 is markedly different than that found above and below. The majority of the fractures found in this interval were located in a highly fractured interval centered at a depth of about $500 \mathrm{~m}$ (Figure 13). Pore pressure measurements made in the well revealed a zone of artesian pressures from above $394 \mathrm{~m}$ to somewhere above $591 \mathrm{~m}$ [Zoback and Hickman, 1982]. The presence of the artesian zone suggests that impoundment has raised the pore pressure in an aquifer represented, perhaps, by the distinct fracture set found in the interval $305-610 \mathrm{~m}$.

\section{Limekiln Valley, California}

Fracture studies have been performed in three wells drilled near the creeping section of the San Andreas fault in central California. These wells were drilled to depths of about $220 \mathrm{~m}$ in Cretaceous quartz monzonite of the Gabilan Range. The wells were located 2, 4, and $14 \mathrm{~km}$ west of the San Andreas fault (Figure 18).

The Gabilan Range is part of the Coast Ranges province of central California. (For a detailed summary of the geology of this area, see Page [1966] and Compton [1966].) The structural and stratigraphic history of the Coast Ranges province has been quite complex. In the Tertiary, folding, high-angle reverse faulting, thrusting, and strike slip faulting in the Coast Ranges have been more or less simultaneous. All of these types of deformation have affected Plio-Pleistocene deposits in one area or another, implying that all have been at least locally active in the Quaternary. The Gabilan Range itself is a broad granitic complex enclosing numerous large metamorphic relics. Its length is about $75 \mathrm{~km}$ in a northwest-southeast direction, with a maximum width of about $15 \mathrm{~km}$. It is bounded on the east by the San Andreas fault and on the north, west, and south by Cenozoic clastic sedimentary rocks. As a whole, the Gabilan Range appears relatively undeformed, although there is evidence of small-scale folding and lineation.

Geodetic measurements of strain across the San Andreas fault [Thatcher, 1979; Savage and Burford, 1973] have been modeled by the motion of relatively rigid blocks. There has 


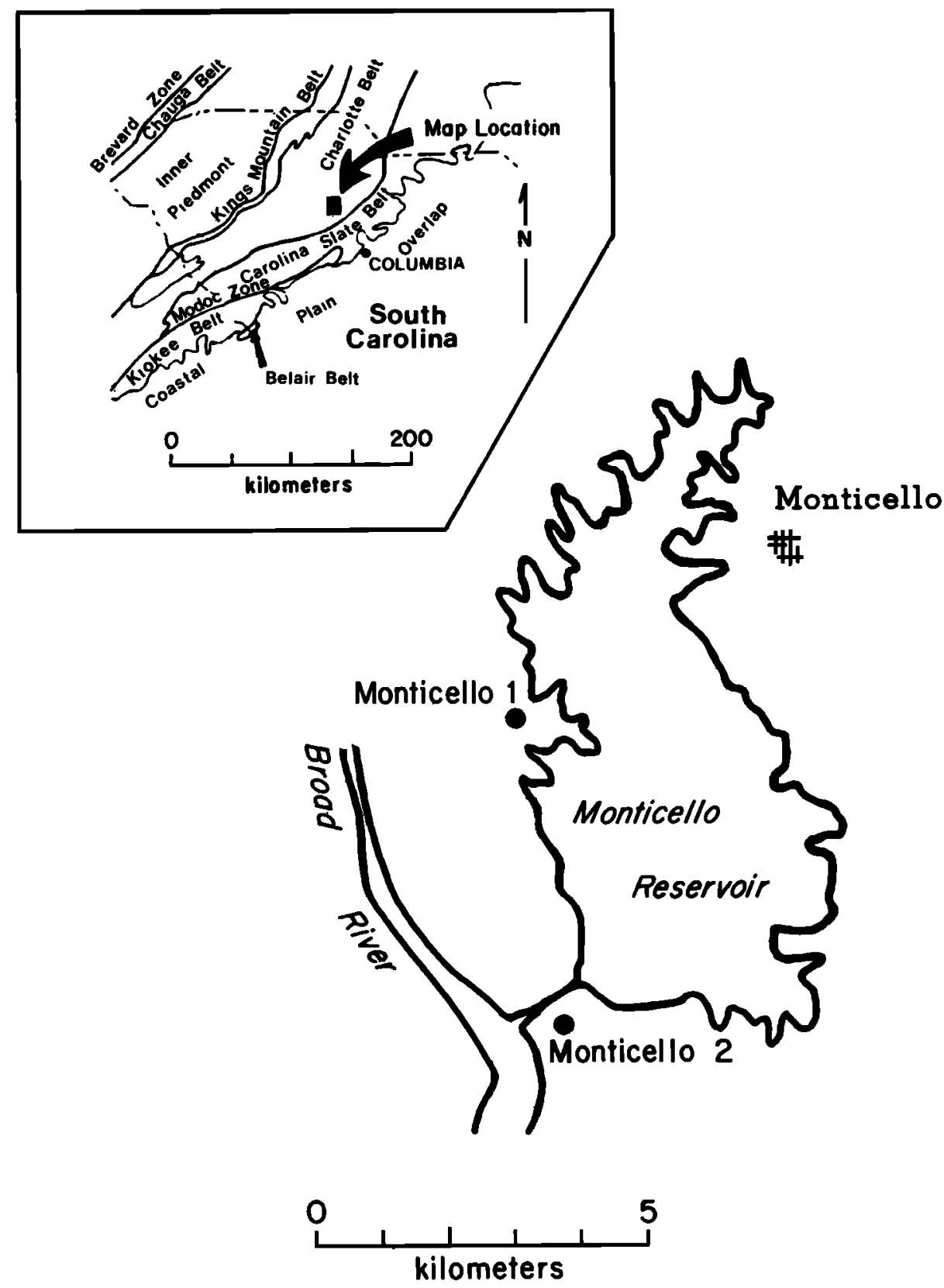

Fig. 12. Map showing location of wells near Monticello Reservoir, Fairfield County, South Carolina. Both wells were drilled in intrusive granodiorite bodies of late Paleozoic age in the Charlotte Belt.

been no evidence of strain accumulation on either side of the fault system, so that the relative motion appears to be accommodated by slip accumulation in a very narrow zone centered on the San Andreas fault. Such motion is consistent with a roughly north-south regional compression. However, an analysis of fold trends [Page, 1966] indicates that the direction of maximum shortening is $\mathrm{N} 35^{\circ}-50^{\circ} \mathrm{E}$. Also, earthquake focal mechanisms indicate general north-south compression but with considerable scatter [Zoback and Zoback, 1980]. Gawthrop [1977], in a study of the seismicity of the central coastal region of California, found that the least horizontal principal stress was oriented about $\mathrm{N} 60^{\circ} \mathrm{W}$. This conclusion was based upon an average of 30 events, with approximately equal numbers of strike slip and thrust events. The direction of maximum compression varied from $\mathrm{N} 10^{\circ} \mathrm{W}$ to $\mathrm{N} 60^{\circ} \mathrm{E}$, with an average of about $\mathrm{N} 30^{\circ} \mathrm{E}$, close to the direction inferred from fold orientations.
Televiewer picture quality was generally good in wells LKB and LKC, but well LKD was so intensely fractured that the overall data quality is relatively poor. The fracture density (number of fractures per meter) is greater in these wells than in any of the other wells studied (compare Figures 6, 16, and 19). LKC, the least fractured of the Limekiln wells is more densely fractured than Mojave 4 and Monticello 2, the most densely fractured wells in the other two data sets. Only in LKC is there a possible indication that the number of fractures is decreasing with depth. There is no relation between proximity to the San Andreas fault and the density of fracturing in these wells. LKD, the well farthest from the fault, encountered the most fractures, while LKB, the well closest to the fault, lies between LKC and LKD in fracture density.

Poles to dipping fracture planes and orientation-density plots for each well are presented in Figure 20. The fractures encountered in the Limekiln wells seem to belong to a few 


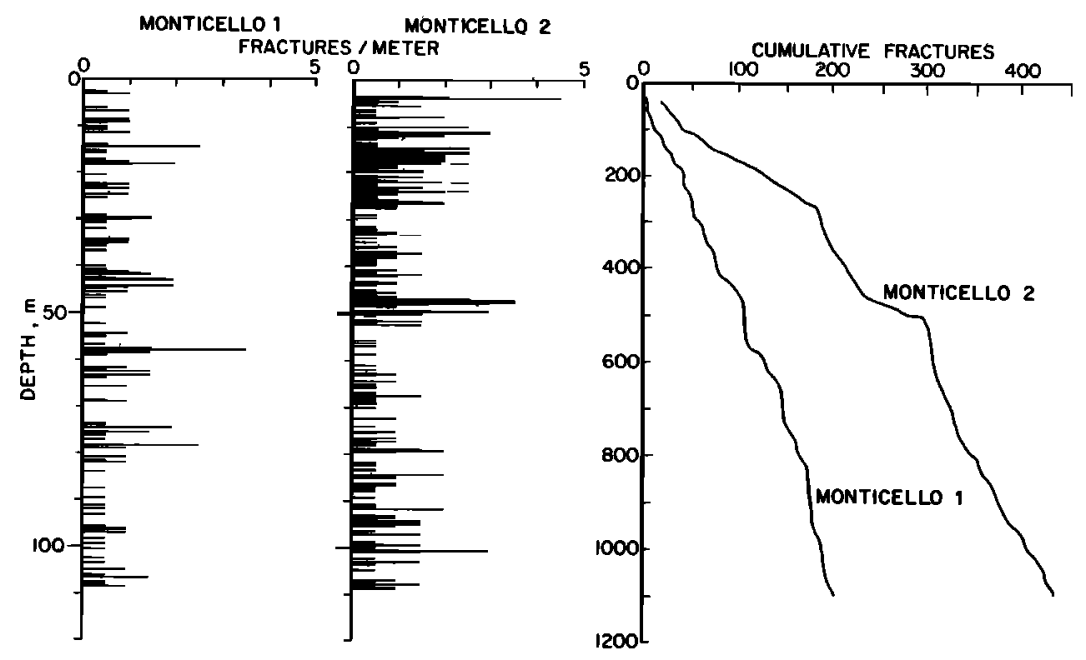

Fig. 13. Frequency plots of the number of fractures per meter plotted as a function of depth for Monticello 1 and 2 plotted as functions of depth. The number of fractures encountered in Monticello 2 was about 3 times that encountered in Monticello 1 and there is little indication in these wells of a decrease in the number of fractures with increasing depth.

well-developed fracture systems as, in each case, the maximum contour on the density plot is at least $10 \sigma$. In well LKB, located $2 \mathrm{~km}$ west of the San Andreas faui', two significant clusters of poles are observed. The most significant cluster $(>16 \sigma)$ has a mean strike of about $\mathrm{N} 60^{\circ} \mathrm{W}$ and $\operatorname{dip}$ of $60^{\circ} \mathrm{W}$. The secondary cluster $(>10 \sigma)$ has an approximate mean strike of $N 65^{\circ} \mathrm{E}$ and dip of $55^{\circ} \mathrm{E}$. There are also two clusters in the orientationdensity plot for well LKC, which is located $4 \mathrm{~km}$ from the San Andreas fault. The most significant cluster $(>10 \sigma)$ has an approximate mean strike of $\mathrm{N} 20^{\circ} \mathrm{W}$ and $\operatorname{dip} 65^{\circ} \mathrm{W}$, while the
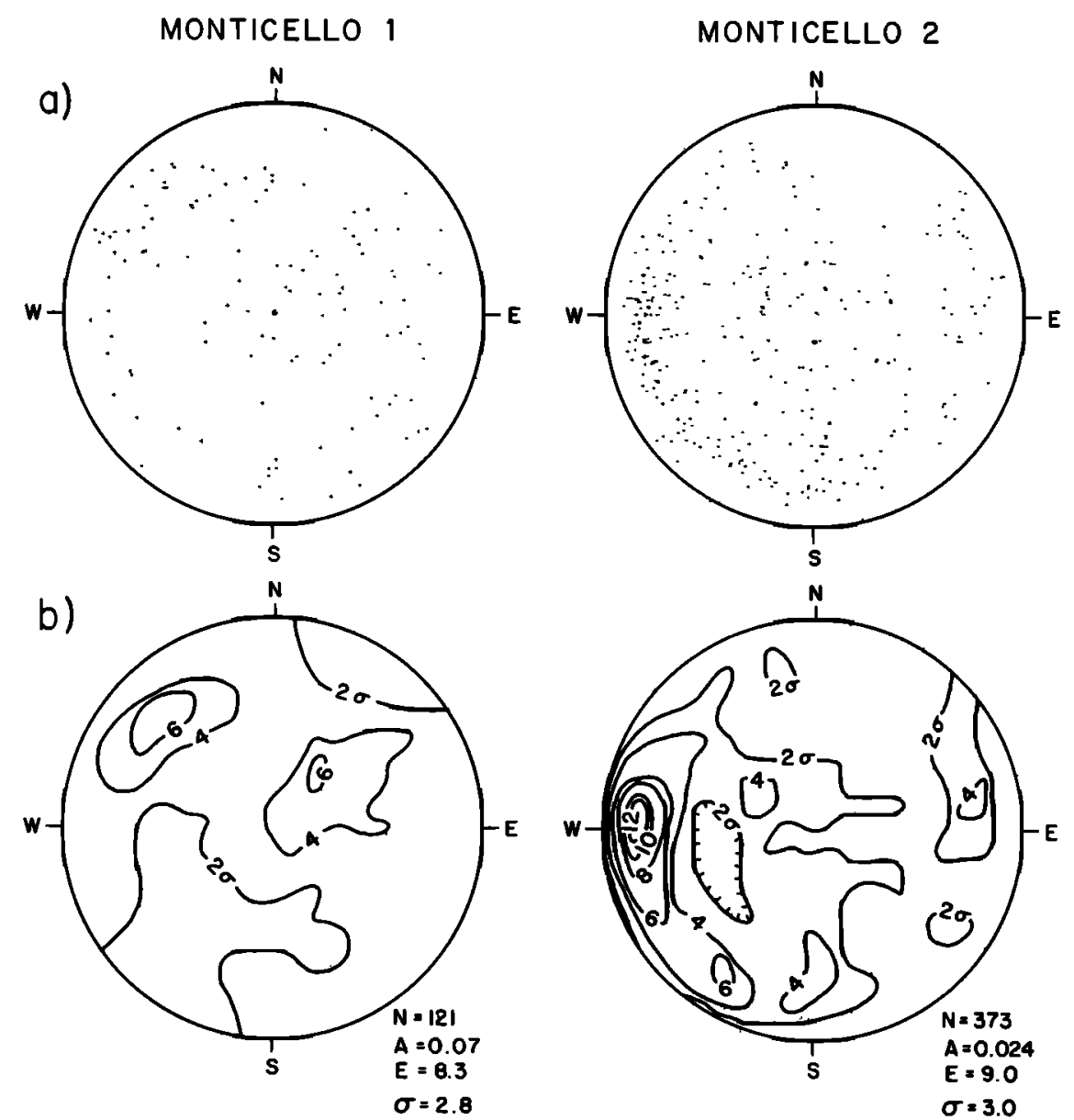

Fig. 14. Lower hemisphere, equal-area diagrams for Monticello 1 and 2. (a) Poles to all dipping fractures. (b) Orientation-density diagrams for all dipping fractures. Although located only $5 \mathrm{~km}$ apart, the fracture patterns found in these wells are very different. 


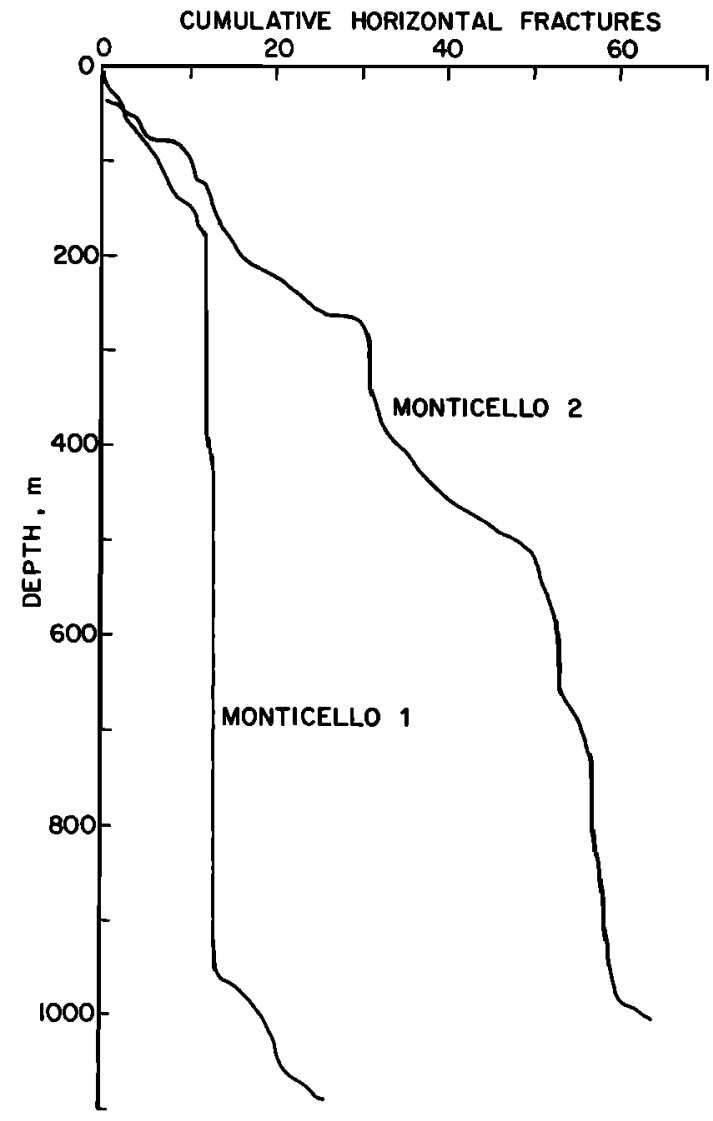

Fig. 15. Cumulative number of horizontal fractures plotted as a function of depth for Monticello 1 and 2. About half of the horizontal fractures in each well were found at depths above $300 \mathrm{~m}$. Several horizontal fractures were also found at depths of about $1 \mathrm{~km}$ in both wells and in the highly fractured intervals between about $\mathbf{4 0 0}$ and 500 $m$ in Monticello 2.

secondary cluster $(>6 \sigma)$ has an approximate mean strike of $\mathrm{N} 50^{\circ} \mathrm{W}$ and $\operatorname{dip} 55^{\circ} \mathrm{E}$. The fracture population picked for LKD is only a subset of the total population due to the intense fracturing and resultant data quality problems. Three clusters are apparent on the orientation-density plot for well LKD, located $14 \mathrm{~km}$ from the fault. The most significant cluster $(>14 \sigma)$ has an approximate mean strike of $N 10^{\circ} \mathrm{E}$ and dip of $60^{\circ} \mathrm{W}$. The two lesser clusters $(>8 \sigma)$ have approximate orientations of $\mathrm{N} 5^{\circ} \mathrm{W}$, dip $65^{\circ} \mathrm{E}$ and $\mathrm{N} 40^{\circ} \mathrm{E}$, dip $65^{\circ} \mathrm{E}$; these two clusters may not be statistically distinct. Orientation-density plots for the upper $110 \mathrm{~m}$ and $110 \mathrm{~m}$-TD for each well are shown in Figure 21. A comparison of the fracture orientations in the shallow and deep sections with those of the entire well indicates that the orientations are consistent throughout each entire well.

\section{Fracture Orientation and Regional Stresses}

Theories of natural fracture genesis can be divided into four basic groups: (1) tensile fractures due to applied compressive stresses, e.g., longitudinal splitting [Jaeger and Cook, 1969] found in planes perpendicular to the direction of least compression [see Engelder and Geiser, 1980], (2) shear fractures due to compressive stresses, (3) tensile fractures which accommodate extension due to a net tensile stress or to the removal of confining stresses, e.g., fracturing due to residual stresses [Engelder, 1979], and (4) natural hydraulic fracturing [Secor, 1965]. Conjugate pairs of shear fractures may develop, with an angle of about $30^{\circ}$ between the direction of maximum compressive stress and the fracture planes; however, often only one of the conjugate pairs becomes a well-developed fracture set [Wilcox et al., 1973].

The measured shear stresses in these wells are currently low (less than 100 bars) [Zoback et al., 1980; Zoback and Hickman, 1982], even in unfractured intervals. If such low shear stresses are representative of the stress state under which these fracture sets were formed, extensive development of shear sets would not be expected and most of the fractures would be of tensile origin. It is interesting to note, however, that in several cases (e.g., in LKC and LKD, Figure 20) the pole clusters in the orientation-density plots could be interpreted as indicative of the presence of conjugate shear fracture sets. Whether these clusters are due to the fractures having formed in shear, to the results of shear motion on favorably oriented, preexisting tensile fractures, or to processes not involving shear stresses

$$
\text { MON T I CELLO I }
$$
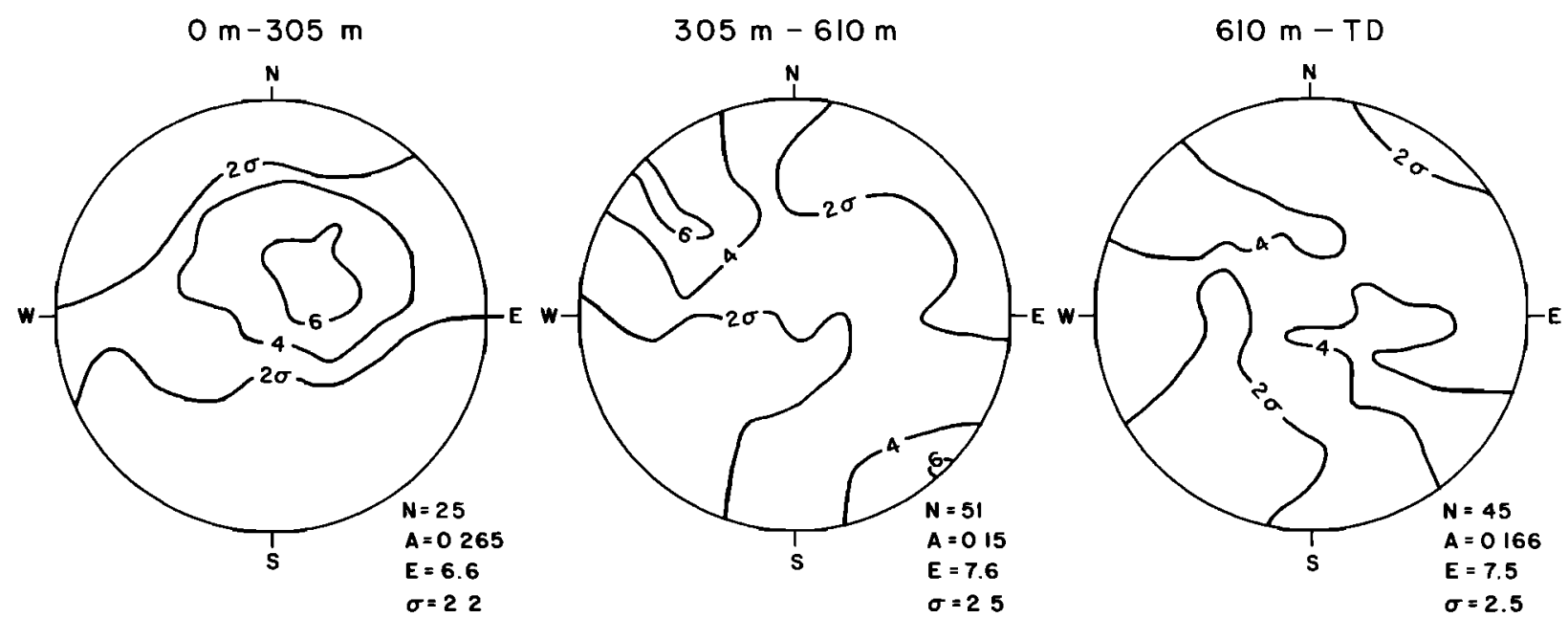

Fig. 16. Orientation-density diagrams for Monticello 1 for the intervals surface $-305 \mathrm{~m}, 305-610 \mathrm{~m}$, and $610 \mathrm{~m}-\mathrm{TD}$. Different fracture distributions are found in each of these intervals: shallow dipping, northwest striking fractures in the upper interval; southeast dipping and northeast striking fractures in the intermediate interval; and a random distribution in the lower interval. 


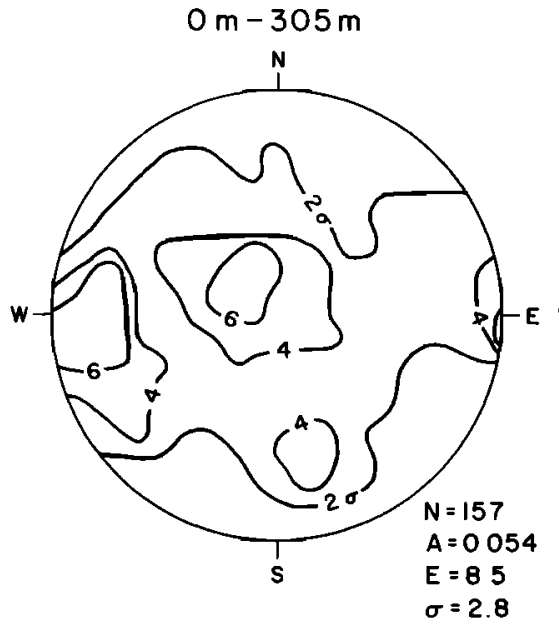

$M O N$ T I C E L L O 2
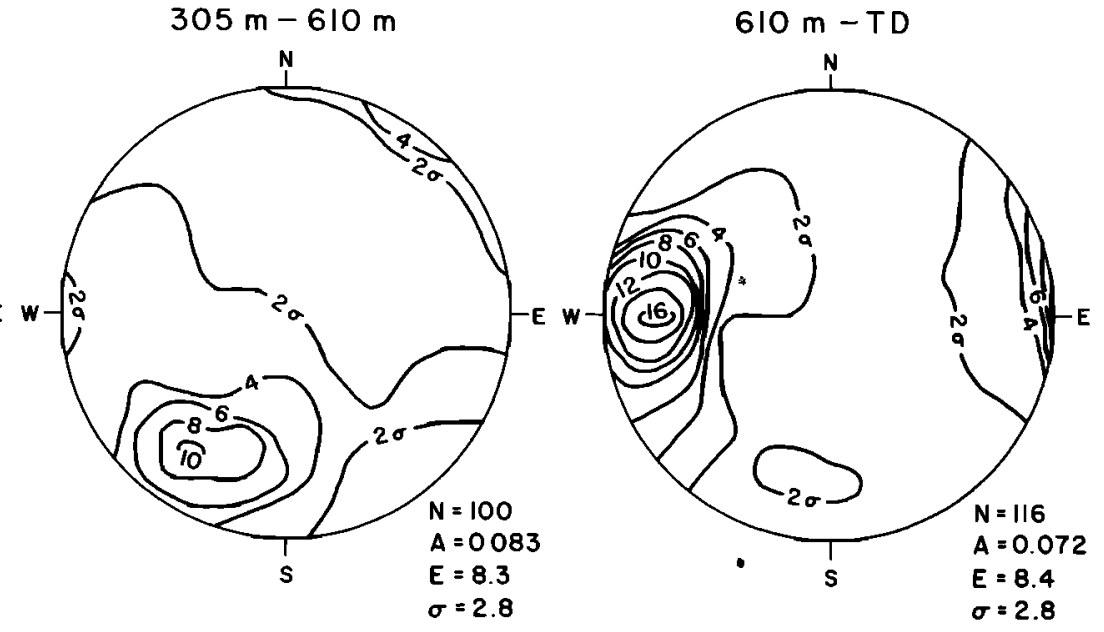

Fig. 17. Orientation-density diagrams for Monticello 2 for the intervals surface- $305 \mathrm{~m}, 305-610 \mathrm{~m}$, and $610 \mathrm{~m}-\mathrm{TD}$. In the upper interval two significant pole maxima are found at the $6 \sigma$ level. One of the maxima is part of the north-south striking set found when the fracture population of the entire well was considered (Figure 14). The second shallow dipping group shows up as a slight $(>4 \sigma)$ concentration in Figure 14. In the intermediate interval a strong northwest striking, northeast dipping set is found. Most of the fractures in this interval are found in the densely fractured zone at about 500-m depth. In the bottom interval the north-south striking fracture set is very prominent; there is little evidence below $600 \mathrm{~m}$ for the northwest striking set of the intermediate interval.

cannot be determined here. From the televiewer data it is impossible to determine whether the fracture sets are of shear or tensile origin or whether any shear deformation has occurred across the fractures subsequent to their creation.

The Mojave and Limekiln Valley wells were located close to the San Andreas fault. The stress field responsible for causing displacement on the fault and the deformation associated with faulting might be expected to affect the fracture distributions. For example, Friedman [1969] studied the macrofracture and microfracture distributions from cores recovered from wells drilled near the Oak Ridge fault, a major reverse fault in the Ventura basin. Friedman concluded that conjugate shear sets of fractures had developed, with one set parallel to the fault plane. He also concluded that the abundance of microfractures increases with proximity to the fault and is independent of the depth of burial. The Mojave and Limekiln wells closest to the San Andreas fault were $2 \mathrm{~km}$ away from it. It is possible that closer to the fault the fracture orientations may parallel the San Andreas (Friedman's [1969] data generally came from within a half kilometer of the mapped subsurface location of the Oak Ridge fault). However, the data presented here show that there is no tendency for the fracture planes to align themselves with the San Andreas fault nor is there an increase in fracture density as the fault is approached.

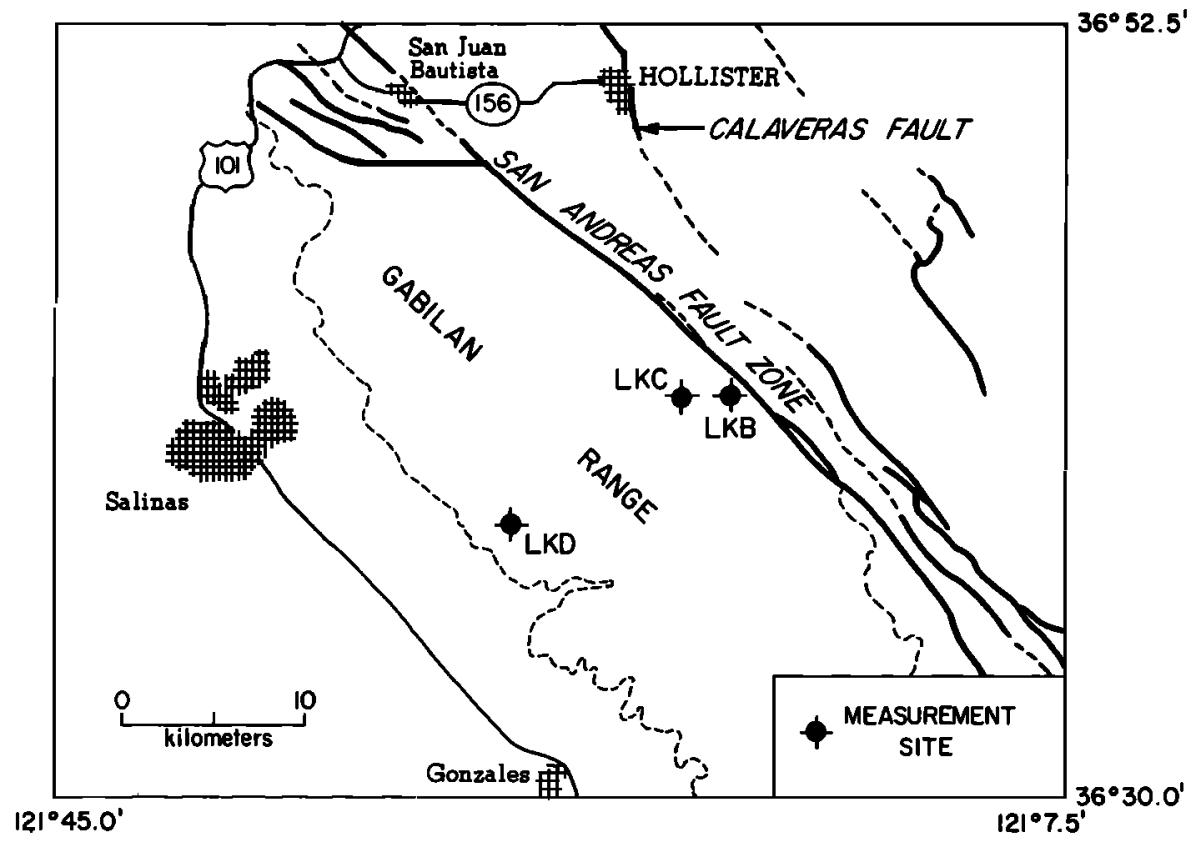

Fig. 18. Map showing location of wells near Hollister, California. Wells LKB, LKC, and LKD are 2, 4, and $14 \mathrm{~km}$ southwest of the San Andreas fault, respectively. These wells were drilled in Cretaceous quartz monzonite. 

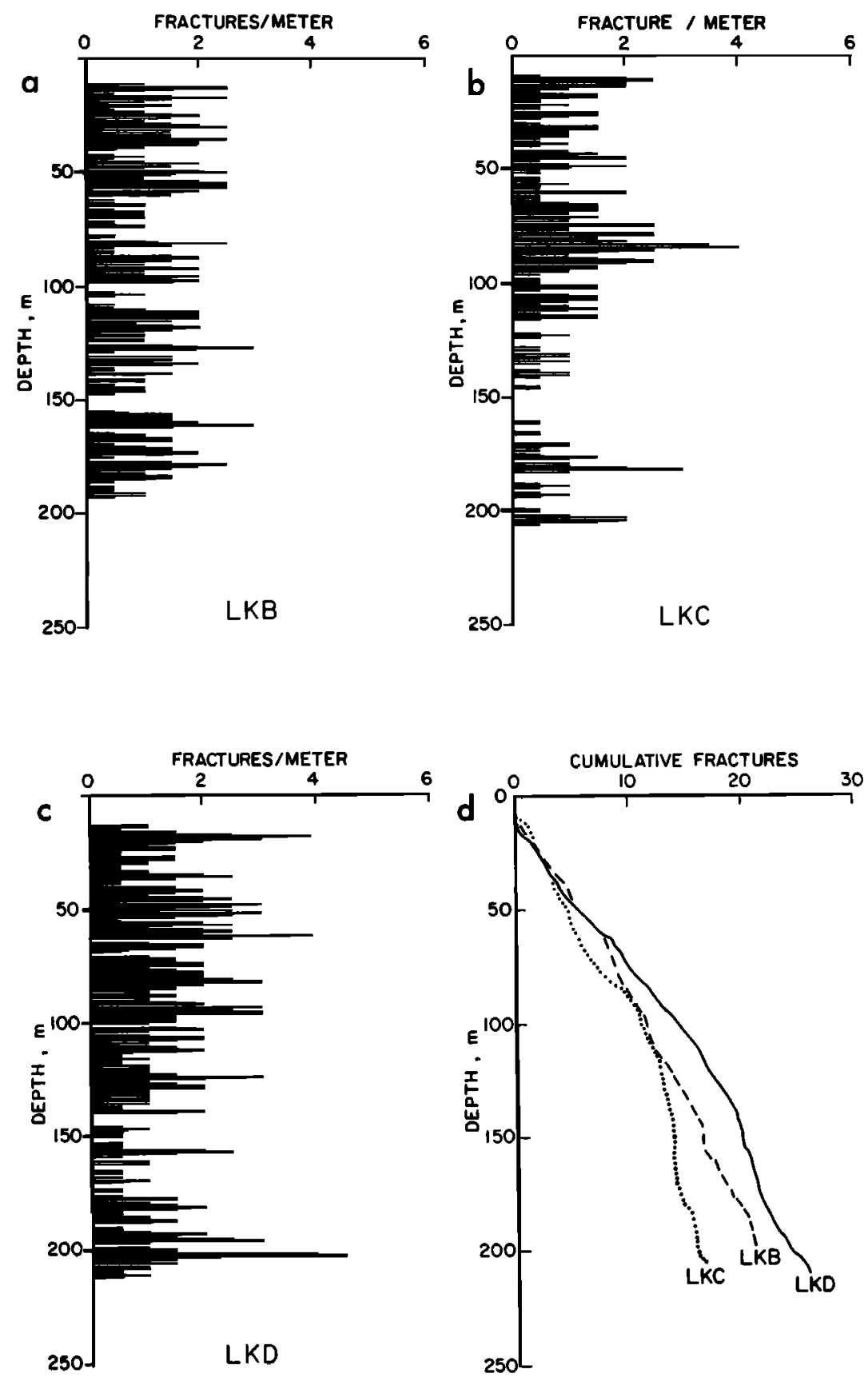

Fig. 19. (a)-(c) Frequency plot of number of fractures per meter plotted as a function of depth for wells LKB, LKC, and LKD, respectively. $(d)$ Cumulative number of fractures plotted as a function of depth. In general, these wells encountered more densely fractured rock than any of the others in this study. Again, there is only a slight tendency for the number of fractures to decrease wtih depth. Also, there is no tendency for the number of fractures to increase near the San Andreas fault.

At Monticello Reservoir, the current local stress field has been determined by in situ stress measurements using the hydrofracture technique [Zoback and Hickman, 1982] and from earthquake focal mechanisms [Talwani et al., 1978]. In Monticello 1 and 2, the difference in magnitude between the two horizontal principal stresses is relatively small except at shallow depth where the greatest horizontal principal stress is substantially greater than the vertical stress. As discussed by Zoback and Hickman, this vertical stress profile is indicative of conditions conducive to thrust-type faulting in the upper $300 \mathrm{~m}$ or so if appropriately oriented fracture planes are present. Seismologic studies confirm that the reservoir-induced earthquakes which have been recorded in this area are apparently occurring at depths of less than $1 \mathrm{~km}$ [Talwani et al., 1978]. The earthquakes appear to occur in clusters and apparently do not define linear fault planes. Events in the different clusters all have slightly different composite focal mechanisms. Most earthquakes are of the thrust type. A comparison of focal mechanisms for earthquakes close to the Monticello 1 site (Figure 18) with the shallow fracture orientations in the well shows fairly good agreement of possible fault planes and significant groupings of natural fractures [Zoback and Hickman, 1982]. A comparison of pole densities in the upper third of Monticello 2 (34-305 m) with composite focal mechanisms for earthquakes occurring near that well site also shows a good correlation with one of the possible fault planes. Thus, the shallow earthquakes 

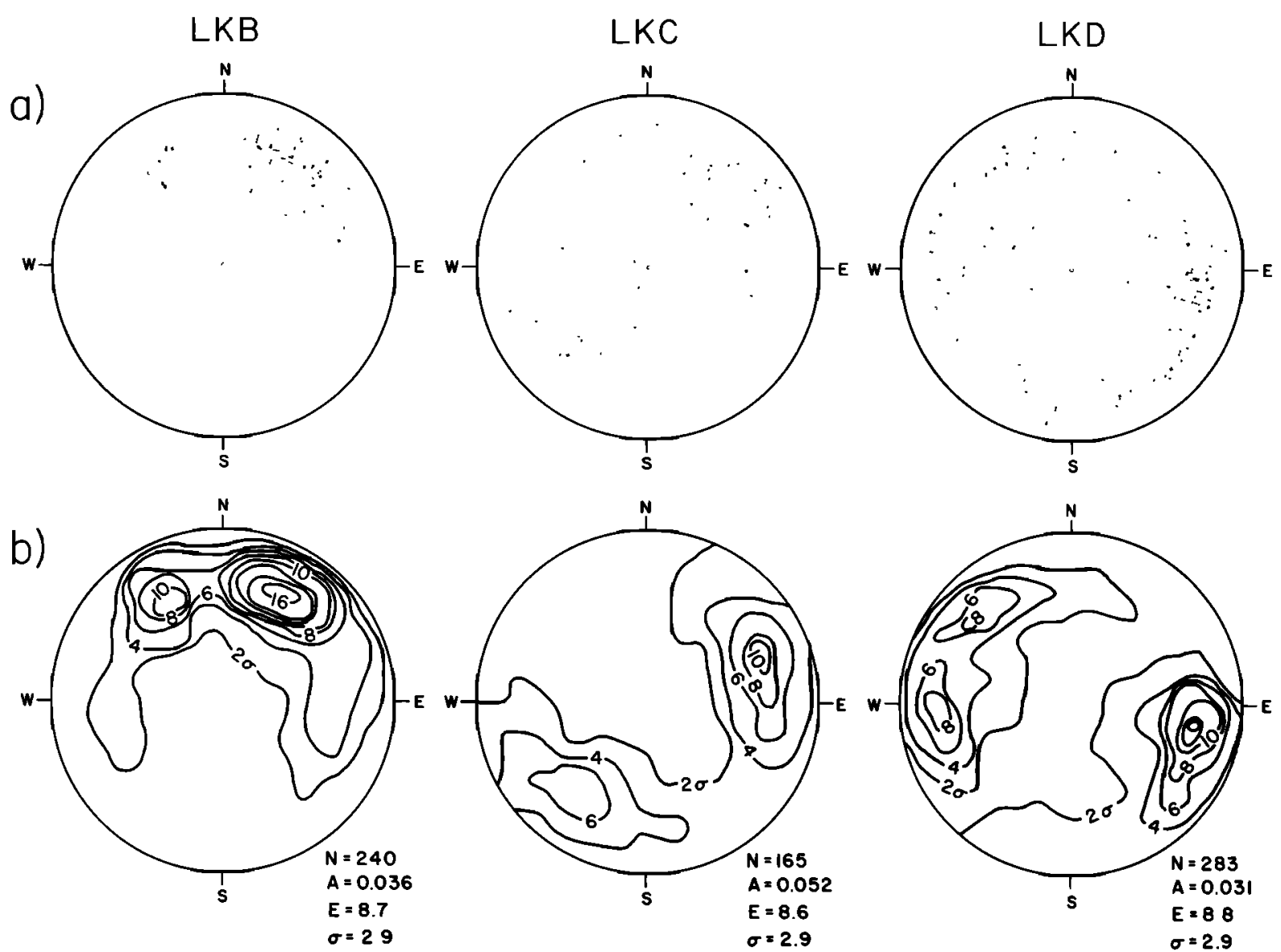

Fig. 20. Lower hemisphere, equal-area diagrams for LKB, LKC, and LKD. (a) Poles to all dipping fractures. (b) Orientation-density diagram for all dipping fractions. In each well, dense pole concentrations were found. Note that, again, there is no significant fracture orientation common to each of the populations.

at Monticello Reservoir seem to be associated with shear motion on preexisting fractures such as those encountered in these wells.

As shown in Figures 7, 14, and 20, the orientation of significant fracture clusters varies rapidly from well to well in a given region. If the fractures in any area are the result of regionally applied stresses, this difference of fracture orientations would imply that several fracture mechanisms are involved and/or that extensive postfracture deformation has occurred. Alternatively, the varied fracture orientations could be the result of local variations or amplifications of the stress field.

Further complications are caused by lithology variations. For example, the difference in fracture density observed in Mojave 1, drilled entirely in sandstone, and the other Mojave wells, drilled in crystalline rock, may be due in part to the different thermal histories of these rock units.

Clearly, the major complication in attempting to analyze the mechanism of fracture formation in the upper crust is the uncertainty of the geologic history of the rock mass. Rocks may undergo repeated tectonic loadings with resultant folding, fracturing, and faulting. Each tectonic cycle may add its own distinct fracture set, or preexisting fracture sets may be modified. The fractures or joints which are observed today reflect the entire deformational history of the rock. The existence of fracture sets which cannot be explained on the basis of the current stress field is not unexpected. As examples, Tchalenko and Ambraseys [1970], Freund [1974], and Wilcox et al. [1973] found from field mapping and clay model experiments that the orientations of fractures near faults may change with time and deformation, and Hodgson [1971] found little correlation of joints with fold axes in his field mapping of the Comb Ridge area of the Colorado Plateau.

\section{SUMmaRY AND CONCLUSIONS}

In this paper, observations of the natural fracture distributions found in $\mathbf{1 0}$ wells from three different regions of North America have been presented. All but one of these wells were drilled in granitic rock. Numerous fractures were found throughout each well, and only a slight decrease of fracture density was observed with depth. Thus, from the data presented here, fractures in crystalline rock could probably be expected at depths far in excess of $1 \mathrm{~km}$. In some wells, fractures seemed to be relatively uniformly distributed with depth, while in others they were primarily concentrated in densely fractured intervals.

At least one statistically significant concentration of fracture planes was found in every well. In the Mojave and Limekiln Valley wells, these significant fracture concentrations did not vary much with depth. However, in the Monticello wells, more variation of fracture orientation with depth was found. In all of the wells, most fractures were steeply digging, and few horizontal fractures were observed.

The fracture density in the wells was found to vary significantly within a given region due, apparently, to both differences in lithology (in the Mojave wells) and/or local structural or stress concentration effects (in the Monticello wells). The orientation of the most significant fracture concentration was also 

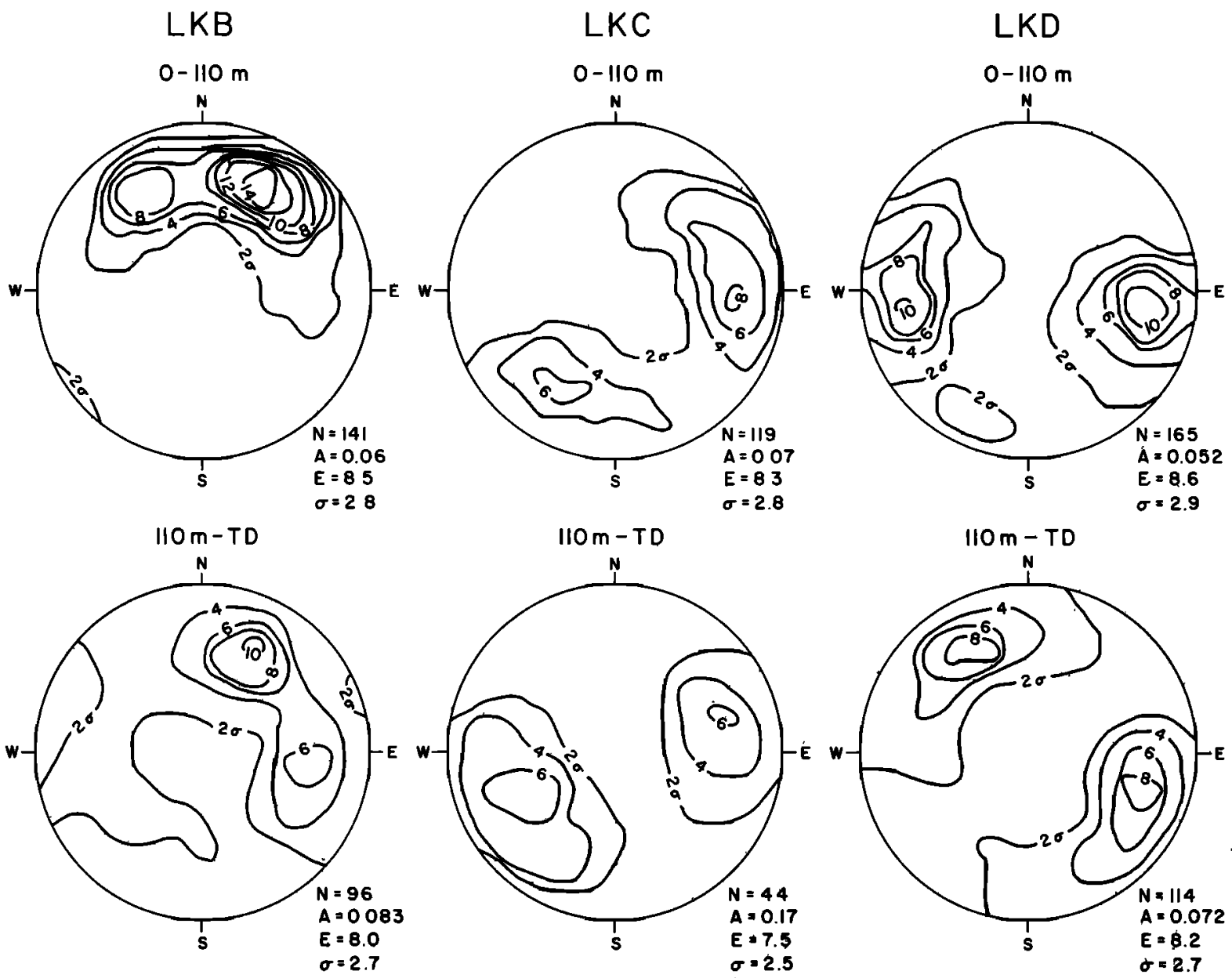

Fig. 21. Lower hemisphere, equal-area orientation-density diagrams for the upper (top row) and lower (battom row) sections of LKB, LKC, and LKD to show any variation of fracture orientation with depth. Little variation of fracture orientation with depth is seen in these wells.

found to be highly variable within a region. No trends related to such nearby large-scale structural features as the San Andreas fault were observed. As a result, in no area could there be predicted a simple, genetic relationship between all of the fracture sets and a regional stress field or structure. The observed fractures may have formed in tension or shear; the mode of fracture formation cannot be predicted from the televiewer data. Many factors could be responsible for the complex fracture patterns observed in each area.

In general, little variation of fracture orientation with depth was observed in the wells studied. Thus, surface fracture patterns are probably a good indication of the orientation of fractures in the upper kilometer of the crust. However, from the observations presented here, it appears unlikely that the number, orientation, or type of fractures to be encountered in situ could have been predicted solely from studies of regional geologic structures or the regional stress field since (1) the number of fractures and their orientations varied considerably from site to site in each of the areas studied and (2) ho obvious genetic relationship was observed between the fractures and the geologic structures or the regional stress field. Until our knowledge of the local geologic history and its effect on fracture formation improves, an understanding of the fracture systems commonly found in situ will generally require detailed, local, subsurface studies.

\section{REFERENCES}

Brace, W. F., An extension of Griffith theory of fracture to rocks, $J$. Geophys. Res., 65, 3477-3480, 1960.

Brace, W. F., Permeability of crystalline and argillaceous rocks: Status and problems, Int. J. Rock Mech. Min. Sci., 17, 241-251, 1980.

Budiansky, B., and R. J. O'Connell, Elastic moduli of cracked solids, Int. J. Solids Struct., 12, 81-97, 1976.

Compton, R. R., Granitic and metamorphic rocks of the Salinian block, California Coast Ranges, in Geology of Northern California, E. H. Bailey, ed., Bull. Calif. Div. Mines Geol., 190, 277-287, 1966.

Dames and Moore, Supplemental geologic investigation Virgil C. Summer Nuclear Station-unit one Fairfield County, South Carolina for South Carolina Electric and Gas Company, report, 61 pp., Washington, D. C., 1974.

Dibblee, T. W., Jr., Areal geology of the western Mojave Desert, California, U.S. Geol. Surv. Prof. Pap., 522, 153 pp., 1967.

Engelder, T., The nature of deformation within the outer limits of the central Appalachian foreland fold and thrust belt in New York state, Tectonophysics, 55, 289-310, 1979.

Engelder, T., and P. Geiser, On the use of regional joint sets as trajectories of paleostress fields during the development of the Appalachian Plateau, New York, J. Geophys. Res., 85, 6319-6341, 1980.

Fisher, G. W., F. J. Pettijohn, J. C. Reed, Jr., K. N. Wemer (Eds.), Studies of Appalachian Geology: Central and Southern, 460 pp., Interscience, New York, 1970.

Freund, R., Kinematics of transform and transcurrent faults, Tectonophysics, 21, 93-134, 1974.

Friedman, M., Structureal analysis of fractures in cores from Saticoy field, Ventura County, California, Am. Assoc. Pet. Geol. Bull., 53, $367-389,1969$. 
Gawthrop, W. H., Seismicity and tectonics of the central California coastal region, M.S. thesis, 76 pp., Univ. of Colo., Boulder, 1977.

Hadley, K., Comparison of calculated and observed crack densities and seismic velocities in Westerly granite, J. Geophys. Res., 81, 3484-3494, 1976.

Hodgson, R. A., Regional study of jointing in Comb Ridge-Navajo Mountain area, Arizona and Utah, Am. Assoc. Pet. Geol. Bull., 45, $1-38,1961$.

Jaeger, J. C., and N. G. W. Cook, Fundamentals of Rock Mechanics, 515 pp., Chapman and Hill, London, 1969.

Kamb, W. B., Ice petrofabric observations from Blue Glacier, Washington, in relation to theory and experiment, J. Geophys. Res., 64, 1891-1910, 1959.

Lisowski, M., and J. C. Savage, Strain accumulation from 1964 to 1977 near the epicentral zone of the 1976-1977 earthquake swarm southeast of Palmdale, California, Bull. Seismol. Soc. Am, 69, 751$756,1979$.

McGarr, A., Violent deformation of rock near deep-level, tabular excavations-seismic events, Bull. Seismol. Soc. Am., 6I, 1453-1466, 1971.

McGarr, A., D. D. Pollard, N. C. Gay, and W. D. Ortlepp, Observations and analysis of structures in exhumed mine-induced faults, Proceedings of Conference VIII: Analysis of Actual Fault Zones in Bedrock, U.S. Geol. Surv. Open File Rep., 79-1239, 101-120, 1979.

Noble, L. F., The San Andreas fault zone from Soledad Pass to Cajon Pass, California, Bull. Calif. Div. Mines Geol., 170, 37-38, 1954.

Nur, A., Effects of stress on velocity anisotropy in rock with cracks, $J$. Geophys. Res., 76, 2022-2034, 1971.

Overbey, W. K., and R. L. Rough, Prediction of oil- and gas-bearing rock fractures from surface structural features, Rep. Invest. U.S. Bur. Mines, 7500, 14 pp., 1971.

Overstreet, W. C., and H. Bell III, The crystalline rocks of South Carolina, U.S. Geol. Surv. Bull., 1183, 126 pp., 1965.

Page, B. M., Geology of the Coast Ranges of California, Geology of Northern California, edited by E. H. Bailey, Bull. Calif. Div. Mines Geol., 190, 255-276, 1966.

Ponti, D. J., and D. B. Burke, Ongoing crustal deformation in the western Mojave region of south-central California (abstract), Geol. Soc. Am. Abstr. Programs, 11, 497, 1979.

Prescott, W. H., and J. C. Savage, Strain accumulation on the San Andreas fault near Palmdale, California, J. Geophys. Res., 81, 4901$4908,1976$.

Savage, J. C., and R. O. Burford, Geodetic determination of relative plate motion in central California, J. Geophys. Res., 78, 832-845, 1973.

Savage, J. C., and W. H. Prescott, Geodimeter measurements of strain during the southern California uplift, J. Geophys. Res., 84, 171-177, 1979.

Sbar, M. L., T. Engelder, R. Plumb, and S. Marshak, Stress pattern near the San Andreas fault, Paimdale, California, from near surface in-situ measurements, J. Geophys. Res., 84, 156-164, 1979.

Secor, D. T., Role of fluid pressure in jointing, Am. J. Sci., 263, 633-646, 1965.

Secor, D. T., Geological studies in an area of induced seismicity at Monticello Reservoir, South Carolina, first technical report, contract 14-08-0001-19124, U.S. Geol. Surv., Reston, Va., 1980.

Snow, D. T., Rock fracture spacings openings, and porosities, $J$. Soil Mech. Found. Div. Am. Soc. Civ. Eng., 94(SM1), 73-91, 1968.

Talwani, P., D. Stevenson, J. Sanber, B. K. Rastogi, A. Drew, J. Chiang, and D. Amick, Seventh technical report, contract 14-08-0001-14553, U.S. Geol. Surv., Reston, Va., 1978.

Tchalenko, J. S., and N. N. Ambraseys, Structureal analysis of the Dasht-e Bayaz (Iran) earthquake fractures, Geol. Soc. Am. Bull., 81, 41-60, 1970 .

Thatcher, W., Episodic strain accumulation in southern California, Science, 194, 691-695, 1976.

Walsh, J. B., The effect of cracks on the compressibility of rock, $J$. Geophys. Res., 70, 381-389, 1965.

Wilcox, R. E., T. P. Harding, and D. R. Seeley, Basic wrench tectonics, Am. Assoc. Pet. Geol. Bull., 57, 74-96, 1973.

Zemanek, J., E. E. Glenn, L. J. Norton, and R. L. Caldwell, Formation evaluation by inspection with the borehole televiewer, Geophysics, $35,254-269,1970$.

Zoback, M. D., and S. Hickman, In situ study of the physical mechanisms controlling induced seismicity at Monticello Reservior, South Carolina, J. Geophys. Res., in press, 1982.

Zoback, M. D., H. Tsukahara, and S. Hickman, Stress measurements at depth in the vicinity of the San Andreas fault: Implications for the magnitude of shear stress at depth, J. Geophys. Res., 85, 6157-6173, 1980.

Zoback, M. L., and M. D. Zoback, State of stress in the coterminous United States, J. Geophys. Res., 85, 6113-6156, 1980.

(Received March 24, 1981;

revised November 10, 1981; accepted March 12, 1982.) 